\title{
Social Protection in a Crisis: Argentina's Plan Jefes y Jefas
}

\author{
Emanuela Galasso and Martin Ravallion ${ }^{1}$ \\ Development Research Group, World Bank, 1818 H Street NW, Washington DC
}

\begin{abstract}
We assess the impact of Argentina's main social policy response to the severe economic crisis of 2002. The program aimed to provide direct income support for families with dependents for whom the head had become unemployed due to the crisis. Counterfactual comparisons are based on a matched subset of applicants not yet receiving the program. Panel data spanning the crisis are also used. We find that the program reduced aggregate unemployment, though it attracted as many people into the workforce from inactivity as it did people who would have been otherwise unemployed. While there was substantial leakage to formally ineligible families, and incomplete coverage of those eligible, the program did partially compensate many losers from the crisis and reduced extreme poverty.
\end{abstract}

Keywords: Crisis; safety net; workfare; unemployment; poverty; Argentina

JEL classifications: H53, I38; J65

World Bank Policy Research Working Paper 3165, November 2003

The Policy Research Working Paper Series disseminates the findings of work in progress to encourage the exchange of ideas about development issues. An objective of the series is to get the findings out quickly, even if the presentations are less than fully polished. The papers carry the names of the authors and should be cited accordingly. The findings, interpretations, and conclusions expressed in this paper are entirely those of the authors. They do not necessarily represent the view of the World Bank, its Executive Directors, or the countries they represent. Policy Research Working Papers are available online at http:/lecon.worldbank.org.

1 The work reported in this paper is part of the ex-post evaluation of the World Bank's Social Protection IV Project in Argentina. The authors' thanks go to staff of the government's Institute of Statistics and Ministry of Labor, who helped greatly in assembling the data required for this paper, and to the World Bank's manager for the project, Polly Jones, for her continuing support of the evaluation effort, and many useful discussions. Paula Giovagnoli provided excellent research assistance. Correspondence: egalasso@worldbank.org and mravallion@,worldbank.org. 


\section{Introduction}

Income transfer programs are a common social policy response to macroeconomic crises. Stated aims vary in practice, but the common (explicit or implicit) goal is to help protect the living standards of those families most adversely affected by the crisis. One of the largest such programs in recent times is the Government of Argentina's Plan Jefes y Jefas (hereafter "Jefes"), introduced in January 2002. This was the main public safety net response to the severe economic and political crisis that hit Argentina at the end of 2001. Unemployment and poverty rates reached record levels during the crisis (World Bank, 2003). Jefes aimed to provide direct income support for families with dependents who had lost their main source of earnings due to the crisis. To assure that the program reached those in greatest need, work requirements were imposed. With support from a World Bank loan (and equivalent counterpart funds from the government), the program expanded rapidly to cover about two million households by late $2002 .^{2}$

Our knowledge about the impacts of such programs has often been limited by a number of factors, including the speed with which crisis programs have to be scaled up and the paucity of appropriate survey data. Yet opinions still abound, often based on little more than casual anecdotes. In the case of Jefes, critics of the program have made claims about fraudulent participation, such as by pointing to cases of registered participants who do not appear to satisfy the program's eligibility criteria, or to weakness in the implementation/effectiveness of the program's counterpart work requirements. At the other extreme, it has been argued that the scheme was a big success in reducing poverty and unemployment in the aftermath of the crisis.

2 In 2002, the Government of Argentina spent about US\$500 million on Jefes, and about a quarter of that was financed through a World Bank loan. For 2003, the estimate is US\$600 million, of which the Bank loan will probably cover about $50 \%$. The loan and counterpart funds cover mainly the payments to beneficiaries. Most costs for materials, supplies, etc. for the workfare projects are covered by the local governments or NGOs sponsoring the projects. 
For example, by one assessment, Jefes is claimed to have accounted for the entire reduction in unemployment that was observed in the year following the crisis, which happened to roughly equal the increase in Jefes registrations over the same period (INDEC, 2002; World Bank, 2003).

Such claims often rest on transparently weak foundations. Anecdotes of abuse may well attract attention but may not be a sound basis for generalization. And claims about (positive and negative) impact often ignore behavioral responses. For example, it is unlikely that a program such as Jefes would not affect labor force participation choices. Then it is unlikely that all participants would have otherwise been unemployed. Similarly, one will clearly overestimate the impact on poverty if one ignores the foregone earnings of workfare participants, who are unlikely to be entirely idle in the absence of the program.

Fortunately, we are in an unusually good situation to rigorously study the impacts of the Jefes program, given that large household surveys were done just before the crisis, in October 2001, and one year later, in October 2002, and that the latter survey identified Jefes participants. Furthermore, one third of the October 2001 sample were followed up in the later survey round.

This paper uses these survey data and the tools of non-experimental program evaluation to address the following (related) questions about the Jefes program:

- Who got assistance? Were the program's eligibility criteria enforced?

- How did participants respond to the program, such as through labor supply and household composition? Did participants come solely from the ranks of the unemployed?

- What was the impact on the incomes of participating households? What share of the income loss due to the crisis was recovered through the program?

- What was the distributional impact?

- What was the impact of the program on aggregate unemployment and poverty? 
In addressing these questions, a key issue will be finding a valid comparison group for Jefes participants, i.e., a group of non-participants who have similar characteristics to the participants with the one exception that they did not get the program. Here we will exploit the fact that we are studying the program in a period of rapid scaling up, which means that there are many current applicants to the program who have not yet received benefits. We will argue that this group has advantages as the source of a comparison group, though we will also address concerns about possible selection bias, such that current participants are different ex ante to the current applicants. One way this might happen is that current participants received larger income shocks from the crisis and so were the first to join the program. Another possibility is that the administrative assignment favored certain groups over others, possibly working against the program's espoused objectives. To help address these concerns we will use matching methods and longitudinal observations, comparing current circumstances for both participants and applicants with a pre-crisis baseline.

The following section gives relevant background on the program. This will motivate the questions addressed by the subsequent empirical work. Section 3 describes our data and gives descriptive results. Section 4 outlines our methods for identifying the program's impacts on income and employment while section 5 presents the results. Section 6 concludes.

\section{The crisis and the public response through the Jefes program}

Argentina fell into a severe economic crisis at the end of 2001. Widespread concerns about the impending collapse of the "convertibility plan" (whereby the Argentine peso was pegged to the \$US) and possible default on external debt led to draconian measures to prevent withdrawals of Bank deposits, which in turn tightened liquidity constraints. The final collapse of the convertibility plan, the subsequent sharp devaluation and default on foreign debt, combined 
with the freeze on deposits, resulted in a large contraction in national output. The almost immediate welfare impacts were severe. Unemployment rose sharply as did various indicators of poverty (Fiszbein et al., 2002; World Bank, 2003). The government's statistics office estimates that the proportion of people living below the poverty line rose from $37 \%$ just prior to the crisis (October 2001) to $58 \%$ a year later (World Bank, 2003). Widespread political and social instability ensued from the economic crisis.

As the government's main safety net response to this crisis, Jefes provided a cash transfer of 150 pesos per month to each eligible individual, representing about one half of mean household income per capita per month in Argentina in 2002. Those formally deemed eligible to participate were unemployed household heads with dependents (children aged less than 18 or incapacitated). In order to enroll, the potential participants had to request participation through the local municipality or through local offices of the Ministry of Labor.

Jefes replaced a previous program, Trabajar. This was a workfare program, though smaller scale than Jefes. Trabajar entailed a tightly enforced work requirement of 30-40 hours, with targeting criteria to help assure that the work was of value to residents of poor communities. Trabajar has been found to have been effective in reaching the poorest, both as workers and residents (Ravallion, 2000; Jalan and Ravallion, 2003). For example, 80\% of Trabajar workers came from the poorest $20 \%$ of the Argentine population (Jalan and Ravallion, 2003).

Given the magnitude of the crisis, the government's explicit aim for the Jefes program was to reach a broader segment of the population than Trabajar. At its inception, Jefes was advertised as a "universal" program, meaning that it was intended that anyone who wanted the transfer amongst those eligible could get it. And (contrary to its predecessor), Jefes did not have an explicitly stated poverty focus. However, genuine universality amongst households with 
unemployed heads and dependents was clearly not sustainable. In early 2002 concerns were emerging about the projected budgetary cost of Jefes. And there were serious signs (based on largely anecdotal evidence) that the program was being heavily captured by people not in most need. Administrative data provided by the Ministry of Labor based on registration records indicated that over half of Jefes participants were in fact women, and probably not "heads of households." In practice, the administrators did not check whether an applicant was really a head of household. There were also anecdotal claims that municipalities and provinces were signing up their employees to cope with the liquidity crisis, as well as claims that local civil servants were sending their wives (not in the workforce) to sign up for Jefes. Possibly the program's benefits were spilling over heavily to people who were not much affected by the crisis, or had the personal resources to cope adequately. At the heart of this concern is the fact that verification of "unemployment" is problematic in Argentina, where over half of employment is in the informal sector. All that the administrators could reasonably verify with confidence was whether an applicants had a formal sector job, and so was registered as such.

Prompted by these concerns, a counterpart work requirement was introduced in early 2002, with the aim of helping to assure that the transfers reached those in greatest need. ${ }^{3}$ The work requirement was not as demanding as for the Trabajar program. Participants were required to do 20 hours of basic community work, training activities, school attendance or employment in a private company with a wage subsidy for six months. The municipalities (together with local NGOs) were in charge of organizing the counterpart activities. Provincial offices of the Ministry of Labor, together with municipal and provincial councils were responsible for monitoring the work activities under Jefes.

\footnotetext{
3 As a condition for financing the program, the World Bank insisted that the vast majority (90\% was the target) of Jefes participants had to be doing the counterpart work.
} 
The counterpart work requirement is likely to entail implicit targeting to the poor, assuming that they tend to have lower reservation wages. ${ }^{4}$ However, given the weak capacity to organize, supervise and enforce the work requirement at local level in such a large program, it is not clear how effective the Jefes work requirement was in practice compared to Trabajar. The history (whereby the work requirement appeared as something of an afterthought), the rapid scaling up, and the circumstances of the crisis, may well have made it hard to enforce the work requirement. And, of course, the self-targeting aspect of the work requirement materializes only insofar as the participants have to comply with it to obtain the transfer.

The behavioral responses to such a crisis, and to such a large public program as Jefes, are clearly of interest. There are various responses that could be expected - both to the crisis (such as through efforts to smooth consumption by income smoothing) and to the policy intervention. It has been argued that the entire participation in Jefes entailed a commensurate reduction in unemployment (INDEC, 2003). This clearly ignores possible behavioral responses to the program through labor supply decisions, either to participate in the workforce or change the total number of hours worked.

Household family composition could well also respond to such a shock, by delaying the formation of new households (Foster and Rosenzweig, 2002) or by changing living arrangements as a response to receipt of a public transfer (Duflo, 2000). Household division (in the form of children sharing) has been anecdotally reported as a potential response to the Jefes program.

Behavioral responses are also relevant to assessing impacts on poverty. Following common practice, INDEC (2002b) calculated the program's poverty impact by subtracting the Jefes payment from the incomes of participants. Thus the poverty rate in the absence of the

\footnotetext{
$4 \quad$ Supportive evidence on this assumption for Argentina can be found in the results of Jalan and Ravallion (2003) on the Trabajar program that preceded Jefes.
} 
program could be readily calculated from the simulated distribution of net incomes. However, this ignores the fact that participants are unlikely to have been idle in the absence of the program, but would have found some sort of work, possibly in the form of casual "odd jobs." Ignoring participants' forgone incomes will clearly lead to an overestimation of the poverty reducing impact of the program.

\section{Data and descriptive results}

We use the October 2001 and October 2002 rounds of the Encuesta Permanente de Hogares (EPH) done by the Government of Argentina's Statistical Institute (INDEC). The survey is only done in large urban areas (representative of $70 \%$ of the total population). Information is collected on employment, incomes, education and household demographics. A subset of the sample is linked as a panel, with approximately one third of the sampled households in 2001 being re-interviewed in 2002. For the purpose of this study, a special module on Jefes participation was administered in October 2002 to those adult members for whom Jefes was not the main occupation. (The existing survey was deemed adequate for those for whom Jefes was the primary occupation.)

Before turning to the household-level analysis it is of obvious interest to see how the grossed-up aggregate participation rate in Jefes from the EPH compares to the administrative data on aggregate registrations. This is complicated by the fact that, while the Jefes program had national coverage, the EPH sample frame excludes $30 \%$ of the population. The Appendix presents calculations of how the EPH participation aggregate compares to the administrative records corresponding to the EPH sample frame. By our preferred method (based on the applicants' places of residence) the grossed-up EPH count of Jefes participants accounts for 91\% of the administrative aggregate. This is a significant discrepancy at the $5 \%$ level, though just 
barely; at the upper bound of its $95 \%$ confidence interval, the survey estimate accounts for $99 \%$ of registered participants. This does not suggest that there is likely to be a serious concern about undercounting of Jefes participation in the EPH relative to its sample frame.

There is a question of how Jefes "eligibility" should be defined in terms of the EPH data. In practice, the status of being unemployed and a head of the household was certified via a signed statement by the beneficiary. However, the only signal of unemployment status that could be reliably checked by the authorities was whether an individual was participating in the formal labor market. It is thus of interest to consider a definition of eligibility that is close to what could be enforced in practice by the program administrators. We will define a sampled adult as "eligible" if he or she is not employed in the formal labor market and lives in a household with a child (under 18 years and belonging either to the head or the spouse) or a handicapped person. We will however point out some important differences between this "practical eligibility" definition and the official "theoretical eligibility" definition.

Table 1 compares Jefes participants from the EPH with households satisfying the program's eligibility criteria. About one third of those receiving the program did not satisfy the eligibility criteria. And about $80 \%$ of those active individuals who were eligible (though not necessarily poor) did not receive the program. Notice that applicants not yet receiving the program were more likely to be ineligible than current recipients.

Tables 2 and 3 give a broader set of descriptive statistics; Table 2 is for the full crosssectional sample in October 2002 while Table 3 gives results for the baseline sample of October 2001. In both cases, we split the sample between current participants and applicants who have not yet joined the program; we will draw a comparison group from the latter, so the comparison 
of characteristics between the two groups is of obvious interest. Comparisons are also drawn between these two groups and all eligible heads and all active adults in the sample.

The average Jefes participant in the sample is female (69\% of participants, as compared to $43 \%$ for all active adults) with an average age of 36 years, married, not a head of household (for $57 \%$ of participants) and has eight years of schooling. Jefes participants are less likely to be heads of households than the sample of all active adults and more likely to be spouses of heads. The participants tend to come from larger households than average -5.4 people per participating household as compared to 4.2 for all active adults — and this difference is due to the presence of more children in Jefes families. ${ }^{5}$ Jefes families tend to be decidedly poorer on average, with a household per capita income that is about $30 \%$ of the mean for all active adults. If one nets out the Jefes transfer payment then participants came from households with an income per person that was only $17 \%$ of the mean for all active adults. It is notable that Jefes participants and applicants tend to have similar characteristics, though we will examine this more carefully later using a multivariate model.

Notice that the families of Jefes participants tend to be poorer on average than eligible heads of households. As we saw in Table 1, there is quite a high incidence of ineligibility amongst Jefes participants, and limited coverage of those eligible. Most of the ineligibility stems from not complying with the dependency criteria (having dependents of the head that are 18 years of age or handicapped).

However, the ineligible Jefes participants are less poor than those eligible. Indeed, as can be seen from Figure 2, when we compared the cumulative distribution function (CDF) of household income per person for eligible participating families with ineligible ones we found

\footnotetext{
$5 \quad$ Note that the extent of multiple participants in the same household is limited: $13 \%(7 \%)$ of the participating individuals (households) live in household with more than one beneficiary.
} 
first-order dominance, such that no matter what poverty line or poverty measure is used the eligible participants are poorer than the ineligible participants. ${ }^{6}$ Most of the ineligibility stems from not complying with the dependency criteria (having dependents of the head that are 18 years of age or handicapped). Tighter enforcement of this criterion would improve the program's performance in reaching the poor, albeit slightly. Turning to the pre-crisis baseline survey for October 2001, we find that $43 \%$ of Jefes participants in October 2002 were employed a year earlier, while $38 \%$ were inactive and only $19 \%$ were unemployed (Table 3 ). The unemployed participants were more likely to be represented in the bottom decile of the income distribution. ${ }^{7}$ Jefes participants and applicants have similar baseline characteristics in the panel.

One possible source of bias in our use of applicants as a comparison group is that the participants may have received larger latent income shocks in the crisis than did the applicants that have not yet joined the program. This could happen if those households who received the largest shock were first to apply and be accepted. Then the measured income losses for the applicants during the crisis will underestimate the counterfactual income losses for participants.

We can assess the likely extent of mismatch in terms of shocks by comparing the income changes under alternative assumptions about the share of foregone income in the construction of the counterfactual income of Jefes participants. Then we can calculate the corresponding income shock using the panel data. The comparison in the distribution of shocks between Jefes participants and the applicants not yet receiving the program gives us an idea of the extent of the bias under alternative hypotheses on the net gains from the program. If our identifying

\footnotetext{
$6 \quad$ This holds for a broad class of additive poverty measures (Atkinson, 1987).

More precisely, $26 \%$ of previously unemployed participants are in the bottom decile of the income per capita distribution in 2001 , as compared to $16 \%$ of the previously inactives and $11 \%$ of the previously employed participants.
} 
assumption holds, the expected change in income in the absence of the program should be the same for participants and their comparison group.

Under a priori plausible assumptions about the foregone income of participants based on evidence for the Trabajar program, we find that the distribution of income shocks is reasonably well balanced between the sample of Jefes participants and the applicants not yet receiving the program. Table 4 gives the distributions of the income shocks for household and individual incomes for various assumptions. We see that the expected change of income in the absence of the program is balanced across the two groups when one assumes a foregone income of about one-third to one half, which is consistent with the estimates by Jalan and Ravallion (2003) for the Trabajar program that preceded Jefes. However, the tighter work requirements on Trabajar may well mean that Jefes forgone incomes are lower. The last column of Table 4 is based on our preferred estimates of foregone income of the Jefes participants; we will explain how these estimates were obtained in the following sections. Again we find a good balance of the income changes between participants and applicants. Table 5 shows where the participants are found in the pre-crisis national distribution of income. For this purpose, Jefes participants were assigned into national deciles based on household income per person in October 2001 . We find that $15 \%$ of the participants were initially in the lowest decile of the income distribution; $40 \%$ are in the poorest $20 \%$. And $90 \%$ were amongst the poorest $60 \%$, which was about the official poverty rate at the time.

To throw further light on the role played by the eligibility criteria, Table 6 shows that unemployed heads of the households with dependents would have been highly concentrated in the bottom $20 \%$ of the income distribution before the program. The Table also gives results for a "theoretical" eligibility criteria close to the program's official aim of reaching unemployed 
heads. (Recall that we have used a weaker definition, closer to what could be implemented in practice given the information available to local administrators.) The theoretical target population identified by the decree turns out to be quite narrowly defined, representing a small fraction $(5 \%)$ of the population at the baseline. About $45 \%$ of the heads have dependents aged less than 18 or incapacitated. Of those, only $12 \%$ of the sample of heads with dependents were unemployed as of October 2001 ( $80 \%$ were employed, and $8 \%$ were inactive).

Contrary to the theoretical target population, these practical eligibility criteria are quite broad and only slightly progressive (Table 7). These criteria, if perfectly enforced, would allow Jefes to reach about $50 \%$ of the poor at a poverty line of about 100 pesos.

To help assess the distribution of gains from the program, Table 7 gives selected points on the concentration curve using the cross section samples, under the assumption of zero foregone income and for our preferred estimates of foregone income (discussed in detail later). Comparable results are also given for the preceding Trabajar program. Figure 1 gives the complete concentration curves. Jefes is clearly not as well targeted as Trabajar. This is consistent with expectations that the work requirement was not as tightly enforced in Jefes. However, spending on Jefes appears to be better targeted than other categories of social spending in Argentina. World Bank (1999) (quoting Gasparini, 1999) presents estimates of the concentration curves for overall social spending indicating that the poorest $20 \%$ receive $22 \%$ of the outlays ( $30 \%$ for the sub-component of social services) while the next poorest $20 \%$ receive $20 \%(19 \%$ for social services $){ }^{8}$

\footnotetext{
8 Analogously, the concentration curve shows that targeting performance for Jefes is better than a median transfer program by international standards and Latin American standards, as indicated by the results of Coady, Grosh and Hoddinott (2002), A median social assistance program in Latin America is $60 \%$ more progressive than a neutral allocation (compared to $25 \%$ of a median transfer program in developing countries).
} 


\section{Methods for assessing impacts}

We follow common practice in defining "impact" as the difference between the outcome indicator with the program and its counterfactual value for participants in the absence of the program. Also following common practice in the evaluation literature, our estimate of the counterfactual will be based on a matched comparison group of non-participants. As in all evaluations, the reliability of this method depends crucially on whether the comparison group has sufficiently similar characteristics to the participants in the absence of the program.

A natural starting point in finding a comparison group for the current participants in Jefes is by studying those individuals who have applied to the program but have not received it yet. We term this group the Jefes applicants. Restricting the comparison group to this sample has the appeal that the applicants have already indicated a preference towards participation in the program (Angrist, 1998). To some extent, unobserved factors influencing participation (such as shocks associated with the crisis) are revealed by the applicants.

However, one cannot rule out latent heterogeneity between participants and applicants that can bias impact estimates on using the applicants as the counterfactual. As we saw in Table 1, the applicants are less likely to satisfy the eligibility criteria than the current participants. To control for observable heterogeneity amongst the applicants we apply propensity matching techniques to construct a counterfactual outcome from the sample of applicants not yet receiving the program. Let $D_{i}$ be an indicator of participation in Jefes; $D_{i}=1$ if individual $i$ participates and $D_{i}=0$ if not. Following Rosenbaum and Rubin (1983), matching methods estimate the outcome without the program by taking weighted averages over outcomes for individuals who did not participate that are observationally similar to the participants in terms of their propensity scores, given by $P\left(X_{i}\right)=\operatorname{Prob}\left(D_{i}=1 \mid X_{i}\right)$, the probability of participating 
conditional on observed (predetermined) covariates $X_{i}$. Matching aligns the distribution of observables between the comparison group and participants.

This leaves the problem of selection bias due to unobservables. To help reduce this bias we exploit a subsample of panel households interviewed in both the baseline (October 2001) and after the program (October 2002) to obtain a double difference (sometimes called "difference-indifference") impact estimator. This eliminates any time-invariant additive selection bias due to unobserved heterogeneity between participants and the applicants not yet receiving the program. Matching in combination with double-difference has been found to be effective in eliminating selection bias, to the extent that it is due to time-invariant omitted effects that might matter to participation (see, for example, Heckman et al. 1997). The panel sample will also allow us to look at how impact varies according to differences in baseline characteristics.

We have data for October 2002 on $N$ participants, indexed $i=1, . ., N$ and $C$ comparators, $j=1, . . C$ in the region of common support, i.e., the set $\left.\left.\left\{i: \hat{f}\left(P_{i} \mid D=1\right)>0\right) \cap \hat{f}\left(P_{i} \mid D=0\right)>0\right)\right\}$ where $\hat{f}$ is the empirical density of the scores. The smaller panel sample contains $n$ and $c$ individuals in the matched treatment and comparison groups. Let $Y_{i t}^{k}$ be the outcome of interest for individual $i$ at time $t$ in state $k$. There are two possible states for the outcome: $k=1$ in the presence of the program, and $k=0$ in its absence and there are two possible dates $t=0$ (October 2001) and $t=1$ (one year later, the date at which program participation is observed). The evaluation problem of estimating the impact of any program stems from the impossibility of observing simultaneously both states for the same individual. Since nobody participates at the baseline, we continue to use $D_{i}$ to denote Jefes participation at $t=1$. Note that $Y_{i 0}^{0}=Y_{i 0}^{1}$ for all $i$. Our matched single difference estimate of the mean impact is: 


$$
S D=\frac{1}{N} \sum_{i=1}^{N}\left(Y_{i 1}^{1}-\sum_{j=1}^{C} W_{i j} Y_{j 1}^{0}\right)
$$

where the $W_{i j}$ 's are the weights in calculating the counterfactual for each participant. We use the local linear weights, which have been found to perform better at the boundaries of the propensity score, where the extent of the bias is greatest for conventional methods (Heckman et al., 1997.) $S D$ identifies the impact of the program in expectation if there is no selection bias; the condition for unbiasedness is that (dropping $i$ subscripts) $E\left(Y_{1}^{0} \mid P(X), D=1\right)=E\left(Y_{1}^{0} \mid P(X), D=0\right)$ where the expectation is taken over the distribution of unobservables. Our matched double difference on the other hand is estimated on the matched panel sample, and is given by:

$$
D D=\frac{1}{n} \sum_{i=1}^{n}\left[Y_{i 1}^{1}-Y_{i 0}^{1}-\sum_{j=1}^{c} W_{i j}\left(Y_{j 1}^{0}-Y_{j 0}^{0}\right)\right]
$$

This will give an unbiased estimate of impact if the selection bias is time-invariant and additive, i.e., $E\left(Y_{1}^{0}-Y_{0}^{0} \mid P(X), D=1\right)=E\left(Y_{1}^{0}-Y_{0}^{0} \mid P(X), D=0\right)$.

\section{Impacts on incomes and employment}

Table 8 gives the probits used for calibrating the propensity score function on the pooled sample of participants and current applicants (who have not yet joined the program). Two probits are given, one for the October 2002 cross-section (to be used for the matched singledifference calculations) and one for the panel. Initial occupational status in 2001 (and the type of occupation) is included in the estimation of the propensity score in the panel sample. Otherwise the explanatory variables used are similar.

The first thing to note is that the probits have low explanatory power for participation. The samples of participants and applicants are clearly quite similar ex ante in terms of observables. We checked the sensitivity of our results for the panel sample to the inclusion of 
baseline household income. The variable was not significant and its inclusion did not affect the subsequent estimates of the net gains from the program.

Given the evident similarity of the Jefes participants and current applicants, it is not surprising that we find a large region of overlapping support, both in the $S D$ and in the $D D$ matching, as can be seen from Figure 3 .

Nonetheless, there are some significant covariates of participation. We find that Jefes participation increases with age and is more likely for females, for households with a higher share of children below 18, and for those who were public employees at the baseline (Table 8). Geographic effects are jointly significant.

On using these probits to estimate the propensity scores for matching we can now calculate $S D$ and $D D$ as given by equations (1) and (2). Table 9 gives our estimates of the program's impacts on incomes and employment. ${ }^{9}$ We give estimates for both household income gains as well as the individual gains for the Jefes participants.

Our mean impact estimates suggest that participants would have had a larger drop in real income in the absence of the program. Our comparison group experienced a mean drop in real income of about 250 pesos per month over this year. For Jefes participants, the decline was 150 pesos. This suggests that Jefes acted as a partial safety net and attenuated the drop in income relative to what their household would have experienced otherwise. We find that net gains are on average between a half and two-thirds of the gross wage, depending on whether one uses $S D$ or $D D$. The single difference method gives lower net gains from the program.

However, we also find considerably greater imprecision in the $D D$ estimates and in the household level $S D$ estimates compared to the individual-based estimates. Indeed, for $D D$

\footnotetext{
9 Real income is adjusted for regional differences in the cost-of-living. In the panel sample, real income figures are at base October 2002. (The annual inflation rate was 39.4\%.)
} 
household income, the $95 \%$ confidence interval includes 150 , implying that we cannot reject the null hypothesis of zero foregone income in this case.

A further indication of the high variance in the double-difference estimates can be found in the household and individual level impact estimates underlying the means in Table 9. While naturally there is great imprecision in the individual estimates of impact, studying the distribution of those estimates gives a useful indication of which of our estimation methods is most plausible. On a priori grounds, it is plausible that the bulk of the income gains will tend to be found in the interval $(0,150)$. We cannot rule out the possibility that some people might have given up a job earning 150 pesos per month to join Jefes (presumably because of differences in the disutility of work), but it seems unlikely. Equally well, it is unlikely that the net income gain would exceed the gross transfer payment under the program.

By this criterion, all but our individual $S D$ estimates are implausible. For $D D$, we find that $20 \%$ of the individual income gains are negative and $60 \%$ exceed 150 pesos. For $30 \%$ of the sample, the $D D$ household income gains are negative while $54 \%$ exceed 150 pesos. For the $S D$ estimates, we find that half of the household income gains are negative and $30 \%$ are greater than 150. However, we find that $83 \%$ of the individual $S D$ estimates are in the interval $(0,150)$; only $5 \%$ of individual income gain estimates are negative, while $12 \%$ are greater than 150 .

In the following discussion we will thus take the individual $S D$ results to be our preferred estimates on a priori grounds. However, we will still give the $D D$ results when they appear to contain insights that cannot be revealed by the estimates based solely on the cross-sectional data.

Turning to the impacts on employment in Table 9, we find that on average about half of the participants gained work as a result of the program: half of these were drawn from unemployment (women and men) and half from inactivity (mostly women). Moreover, on 
average, Jefes participants increased their hours of work by about 10 hours. In this respect, $S D$ and $D D$ results are similar. The results overall are suggestive of foregone income in that the net increase in hours worked is about half the Jefes stipulated work requirement of 20 hours. $^{10}$

It is clear from these results that Jefes did not just displace unemployment. Indeed, roughly as many participants came from those who would otherwise not have been active in the workforce. This implies that assuming that all Jefes participants would have been otherwise unemployed would grossly overestimate the impact of the program on the rate of unemployment.

We can now use our estimates of the program's impact on labor-market status to estimate the impact on the unemployment rate. Our preferred $S D$ estimates from Table 9 imply that $26 \%$ of Jefes participants would have been unemployed if not for the program, while $23 \%$ would have been inactive. Table 10 gives the counterfactual unemployment rates (as well as the activity and employment rates). We also compare these to INDEC's (2002a) estimates that had assumed that all Jefes participants would have been unemployed without the program.

It can be seen that allowing for the behavioral responses implied by our results gives an appreciably lower impact on the unemployment rate. While INDEC's calculation implies a 5.8 percentage point drop in the unemployment rate due to the program, we get an impact of 2.5 points. In contrast to the claim by a number of observers (including INDEC and World Bank, 2003), Jefes was not responsible for bringing down the unemployment rate in the aftermath of the crisis; we find that the unemployment rate would have fallen between May 2002 and October 2002 even without the program.

10 We found that $78 \%$ of Jefes participants doing the work requirement reported exactly the legally required number of hours (20). This may reflect the fact that municipalities, in order to generate work for a large number of participants, employed them for the minimum number of hours. It is also possible that some participants over-reported their number of hours worked to accord with the legal requirements. 
In Table 11 we explore further the $D D$ estimates of impacts. We find that those attracted out of labor market inactivity were primarily women. However, we find no evidence of labor supply responses of other members of the household, other than those from the change of labor status of the beneficiary (the net gains of number of employed/unemployed/inactives mirrors the labor supply changes at the beneficiary level).

Nor are there signs that households responded by changing their household size (such as by sharing children) in order to gain access to the program. Household size rose slightly more amongst participants than amongst applicants, but the difference is not statistically significant. This is not too surprising, given that our results suggest that the program's eligibility criteria were not rigorously enforced. Moreover, the household division might not actually take place to the extent that 'children sharing' represents only a tool to register into the program.

Table 12 stratifies the net gains. We find considerable heterogeneity in impact. Those who were unemployed/inactive before the program had no foregone income, so their income gain from the program is the gross wage. By contrast, those who were previously employed had a high forgone income. Spouses of the head and females had on average larger net gains, given that they are more likely to be drawn to the program from unemployment or inactivity, relative to men, for whom the opportunity cost of Jefes participation was clearly higher. Table 12 also gives $S D$ impact estimates for individual incomes constrained to be within the interval $(0,150)$. This indicates that forgone income accounts for about one third of the Jefes payment. ${ }^{11}$

Using our preferred $S D$ estimates, Figure 4 gives the implied impacts on poverty amongst participants, as indicated by the CDF of income per person. The lower curve gives the observed (post-intervention) CDF, while the upper curve gives the CDF implied by our estimates

11 In our constrained estimates, the individual net income from Jefes represents the main source of individual (household) income for about half (one quarter) of the sampled participants. 
of the impact of Jefes at each sample point. ${ }^{12}$ At a poverty line of around 100 pesos per month, the poverty rate amongst Jefes participants fell from about $82 \%$ to $70 \%$ due to the program. At a poverty line around 50 pesos, the poverty rate among participants fell from about $51 \%$ to $29 \%$.

Figure 5 gives the implied impacts on the poverty rate nationally. The CDF's of income per person pre- and post-intervention are calculated in the same way as for Figure 4. It is evident that the program had only a small impact on the poverty rate nationally, over a wide range of poverty lines. These results are confirmed by Table 13, which gives poverty incidence nationally. The government's two official poverty lines are used; the lower line is called the "indigence line," which is the food component of the full poverty line. The table gives the official estimates in October 2002, the INDEC estimates of the counterfactual poverty incidence for that date assuming no foregone income, and our estimates using our preferred SD estimates of the net income gains. The impacts at the upper and lower poverty lines are negligible in both cases, though a more sizeable (two \% point) decline in extreme poverty is indicated.

A further perspective on the ability of Jefes to reduce poverty can be obtained by using the panel data to compare the actual joint distribution of income between poor and non-poor over time with our estimated counterfactual distribution for Jefes participants (following the methodology in Ravallion et al., 1995). Thus we can distinguish the extent to which a program provides "protection" of those vulnerable to poverty from "promotion" of the poor; promotion refers to the extent to which Jefes helped participants escape poverty, while protection refers to the impact of Jefes on the number who fell into poverty.

Table 14 provides the distribution of poverty incidence over time for the sample of Jefes participants, using the official poverty line and the lower food poverty line provided by INDEC.

12 This is the same counterfactual distribution used to calculate the counterfactual income shocks for the panel sample, as used in the last column of Table 5. 
Looking first at the actual joint distribution, we find that $20 \%$ of the participants were not poor in 2001 but became poor in 2002 , while only $2 \%$ of the poor in 2001 escaped poverty by the following year. $71 \%$ were poor in both period.

We compare this joint distribution with the counterfactual distribution based on our preferred SD individual estimates of the counterfactual incomes in October 2002. Without Jefes, $22 \%$ of the participants were not poor in 2001 but became poor. And only $1 \%$ escaped poverty. The impacts are greater if we focus on the lower poverty line. Then we find that with Jefes, $30 \%$ were not poor in 2001 but poor in 2002. However, in the counterfactual joint distribution (without Jefes), 40\% fell into poverty. The impact on promotion is again lower; with the program, $8 \%$ escaped poverty, while it would have been $5 \%$ without the program.

The results confirm the "social protection" nature of the program. Jefes had a small impact in helping the participants escape poverty. On the other hand, we find that an extra $10 \%$ of the participants would have fallen into extreme poverty in the absence of the program.

What role did the work requirement play? We interpret our results as indicating that the work requirement was having some impact. In the October 2002 cross-section, $80 \%$ of the sampled participants reported having done counterpart work for Jefes. ${ }^{13}$ The extent of forgone income and hours are also suggestive that the work requirement was having an impact. Taking our constrained individual $S D$ estimates to be the most plausible, the mean foregone income is about 50 pesos per month, or one third of the Jefes payment. This is lower than the estimates for

13 Unfortunately, the data do not allow us to define a consistent definition of the type of activity undertaken by the participants. The definition of what represents 'work' is not consistent depending on whether Jefes participation represents the main economic activity of the participants or not. Participants with Jefes as their main activity are defined to be doing a 'controprestaction' if they are working positive hours (among those, about half of them report working for the public sector, 30\% for community service and $8 \%$ report working for a private company). For those whose participation in Jefes is a secondary activity, counterpart work is self-reported community service (32\%), participation in training (41\%), or school attendance $(13 \%)$ as part of the program. 
the Trabajar program in Jalan and Ravallion (2003), who estimated foregone income to be 100 pesos per month - about half the Trabajar wage. However, it is unsurprising that Jefes would have lower foregone income given the general decline in real wages due to the crisis (World Bank, 2003); the opportunity cost of participation in workfare would undoubtedly have been lower in the wake of this crisis. While we cannot reject the null hypothesis of zero foregone income for the double-difference estimate of the impact on household income, this is attributable to the considerably greater noise in this estimator.

\section{Conclusions}

We have studied a large social protection operation, Plan Jefes y Jefas, undertaken by the Government of Argentina, with support from the World Bank, in response to the 2002 crisis. In identifying impact we have used applicants who have not yet been accepted into the program as the source of a comparison group. To help clean out remaining sources of selection bias we have used propensity score matching methods and longitudinal observations following a (pre-crisis) baseline survey.

The Jefes program provided a basic cash transfer to all households satisfying certain eligibility criteria and for about $80 \%$ of participants the transfer payment came with a work requirement. However, it is clear from our results that the program's eligibility criteria were not rigorously enforced. We find that about one third of those receiving the program do not satisfy the eligibility criteria (and about three fourths of those adult individuals who are eligible are not receiving the program). The aim of only targeting unemployed heads of households with dependents was clearly not realized; indeed, our results suggest that a large share of participants were women who would have not otherwise have been in the labor force. About half of the employment gain due to the program came from unemployment and half from inactivity. 
We estimate that the program reduced Argentina's unemployment rate by about 2.5 percentage points. This is less than half of previous estimates that have assumed that all Jefes participants would have otherwise been unemployed. We find evidence that Jefes tended to have a positive opportunity cost for participants, consistent with the work requirement being binding for the many participants. Factoring in the foregone incomes, the program had a small effect on the overall poverty rate, though a more sizeable impact on the incidence of extreme poverty. For example, the program allowed an extra two percent of the population to afford the food component of Argentina's poverty line. A degree of protection from extreme poverty was also achieved; we estimate that an extra $10 \%$ of the participants would have fallen below the food poverty line without the program.

Jefes clearly helped participants, who would have suffered an appreciably larger drop in their incomes without the program. We find that the program's performance in reaching the poor during the crisis was better than is typical of social programs in Argentina. About one half of Jefes participants came from the poorest fifth of Argentine families, and all but 10\% fell below the official poverty line; this is better than average for social spending, though it is not as good as for the program Trabajar that preceded Jefes.

Overall, the Jefes program does appear to have contributed to social protection during the crisis, despite the fact that its actual implementation differed from its design. The work requirement undoubtedly helped in assuring self-selection. We would expect tighter enforcement of the work requirement and eligibility criteria to improve performance in reaching the poor. 


\section{Appendix: Comparison with administrative records}

Comparing the survey aggregates on Jefes participation for the EPH with the administrative records is complicated by the fact that the sample frame for the survey does not coincide with the (national) coverage of Jefes. This can be dealt with by confining the analysis of the administrative data to those areas included in the EPH sample frame. We consider two ways of doing this. In the first, we only use the administrative data for those municipalities included in the EPH sample frame, based on the location of the participants' Jefes registration. In other words, we only consider participants registered in the geographical areas where there is an overlap of municipalities with the sample frame of the EPH. In the second, we restrict the administrative data to those who have their recorded domicile in the EPH sample frame, i.e., we only consider participants whose residence is in the same conglomerate (according to the zip code) as where they receive their payment (boca de pago). This second method deals with cases in which a person registers in a nearby city in which she is not in fact resident.

Table A1 gives the results. The grossed-up estimate of Jefes participation represents about $80 \%$ of the registered applicants from the administrative data. The aggregate from the administrative data is outside the $95 \%$ confidence interval of the survey-based estimate. When we breakdown the aggregates by urban areas, the administrative count is outside the $95 \%$ confidence interval (CI) for 18 areas. And these are all cases in which the survey estimate of participation is lower than the administrative data suggest.

As one would expect, switching to the residence-based assignment of Jefes participants to urban areas reduces the discrepancy. The tighter matching by residence puts the administrative data close to the upper bound of the $95 \% \mathrm{CI}$ in the aggregate, but it still leaves 14 areas for which the survey gives a significantly lower count. 
The results of Table A1 suggest that the survey is under-representing Jefes participation. It is unclear what the source of the discrepancy might be. It could be due to respondent ignorance of Jefes participation, or a conscious desire to hide participation because of formal ineligibility. Alternatively it might reflect over-counting in the administrative data. This could arise if there is some expropriation of the Jefes transfers for other purposes. However, once one allows for the residence-based assignment of participants it does not appear that the discrepancy is so large as to warrant serious concern about sampling bias in the EPH. 


\section{References}

Angrist, Joshua D (1998), "Estimating the Labor Market Impact of Voluntary Military Service using Social Security Data on Military Applicants”, Econometrica, 66(2), 249-288.

Atkinson, A. (1987), “On the Measurement of Poverty”, Econometrica, 55, 749-764.

Fiszbein, Ariel, Paula Giovagnoli and Isidoro Aduriz (2002), “Argentina’s Crisis and its Impact on Household Welfare," Working Paper N.1/02, World Bank Office for Argentina, Paraguay and Uruguay.

Coady, David, Margaret Grosh and John Hoddinott (2002), "The Targeting of Transfers in Developing Countries: Review of Experience and Lessons", Safety Net Primer, World Bank, Washington DC.

Foster, Andrew and Mark Rosenzweig (2002), "Household Division and Rural Economic Growth," Review of Economic Studies 69(4): 839-869.

Duflo, Esther (2000), "Grandmothers and Granddaughters: Old Age Pension and Intra-household Allocation in South Africa," NBER Working Paper 8061.

Gasparini, Leonardo (1999), “Incidencia Distributiva del Gasto Público”, Fundacion de Investigaciones Economicas Latinoamericanas (FIEL), Buenos Aires, Argentina.

Heckman, James., H. Ichimura, and Petra Todd (1997), “Matching as an Econometric Evaluation Estimator: Evidence from Evaluating a Job Training Program," Review of Economic Studies 64(4): 605-654.

INDEC (2002a), “Mercado de trabajo: principales indicadores de los aglomerados urbanos.

Octubre 2002", Anexo 2. Incidencia del Plan Jefes y Jefas sobre las tasas de actividad, empleo y desocupación: hipótesis B, Información de prensa, 12/2002. 
(2002b), "Incidencia de la pobreza y de la indigencia en el Gran Buenos Aires", Anexo 2.

Incidencia del Plan Jefes/Jefas, GBA, Información de prensa, 12/2002.

(2002c), "Incidencia de la pobreza y de la indigencia en los aglomerados urbanos:

Octubre de 2001”, Información de prensa, 4/2002.

(2003), "Incidencia de la pobreza y de la indigencia en los aglomerados urbanos: Octubre

de 2002”, Anexo 2. Incidencia del Plan Jefes/Jefas, Información de prensa, 1/2003.

Jalan, Jyotsna and Martin Ravallion (2003), "Estimating the Benefit Incidence of an Anti-

Poverty Program," Journal of Business and Economic Statistics, 21(1): 19-30.

McKenzie, David (2003), “Aggregate Shocks and Labor Market Responses: Evidence from Argentina's Financial Crisis", mimeo, Stanford University, Department of Economics.

Ravallion, Martin (2000), "Monitoring Targeting Performance when Decentralized

Allocations to the Poor are Unobserved," World Bank Economic Review, 14(2): 331-346.

Ravallion, Martin, Dominique van de Walle and Madhur Gautam (1995), "Testing a Social Safety Net", Journal of Public Economics, 57, 175-99.

Rosenbaum, P. R., and Donald B. Rubin (1983), "The Central Role of the Propensity Score in Observational Studies for Causal Effects," Biometrika, 70: 41-55.

Smith, Jeffrey and Petra Todd (2003), "Is Matching the Answer to LaLonde's Critique of Nonexperimental Methods?" Journal of Econometrics, forthcoming.

World Bank (1999), Poor People in a Rich Country: A Poverty Report for Argentina, Washington DC: World Bank. (2003), Argentina-Crisis and Poverty 2003: A Poverty Assessment.

Report No. 26127-AR, World Bank, Washington DC. 
Table 1: Errors of inclusion/exclusion

\begin{tabular}{|c|c|c|c|}
\hline & Ineligible & Eligible & Total \\
\hline \multicolumn{4}{|l|}{ Applicants /participants } \\
\hline Not receiving Jefes & 677 & 824 & 1,500 \\
\hline row $\%$ & $45.1 \%$ & $54.9 \%$ & $100 \%$ \\
\hline column $\%$ & $40.5 \%$ & $26.3 \%$ & 31.2 \\
\hline Receiving Jefes & 994 & 2,311 & 3,305 \\
\hline row $\%$ & $30.1 \%$ & $69.9 \%$ & $100 \%$ \\
\hline column $\%$ & $59.5 \%$ & $73.7 \%$ & 68.8 \\
\hline Total & 1,671 & 3,134 & 4,805 \\
\hline row $\%$ & 34.8 & $65.2 \%$ & $100 \%$ \\
\hline column $\%$ & $100 \%$ & $100 \%$ & $100 \%$ \\
\hline \multicolumn{4}{|l|}{ All active adults } \\
\hline Not receiving Jefes & 22,285 & 6,763 & 29,047 \\
\hline row $\%$ & $76.7 \%$ & $23.3 \%$ & $100 \%$ \\
\hline column $\%$ & $97.1 \%$ & $80.2 \%$ & $92.6 \%$ \\
\hline Receiving Jefes & 656 & 1,671 & 2,327 \\
\hline Row \% & $28.2 \%$ & $71.8 \%$ & 100.0 \\
\hline column \% & $2.9 \%$ & $19.8 \%$ & $7.4 \%$ \\
\hline Total & 22,940 & 8,434 & 31,374 \\
\hline row $\%$ & $73.1 \%$ & $26.9 \%$ & $100 \%$ \\
\hline column $\%$ & $100 \%$ & $100 \%$ & $100 \%$ \\
\hline
\end{tabular}

Notes: Individual sample of EPH October 2002. A person is deemed to be "eligible" if he or she lives in a household that has dependents (children of the head below 18 or handicapped) and he or she is not in the formal labor market as indicated by receipt of formal job benefits. 
Table 2: Descriptive statistics, cross section for October 2002

\begin{tabular}{|c|c|c|c|c|c|c|c|c|}
\hline & \multicolumn{2}{|c|}{$\begin{array}{c}\text { Jefes } \\
\text { participants }\end{array}$} & \multicolumn{2}{|c|}{$\begin{array}{l}\text { Jefes } \\
\text { applicants }\end{array}$} & \multicolumn{2}{|c|}{$\begin{array}{c}\text { Eligible } \\
\text { heads or spouses }\end{array}$} & \multicolumn{2}{|c|}{$\begin{array}{l}\text { Active adults } \\
\quad(18-65)\end{array}$} \\
\hline & Mean & st.dev. & Mean & st.dev. & Mean & st.dev. & Mean & st.dev. \\
\hline \multicolumn{9}{|l|}{ Individual demographics: } \\
\hline Male & 0.31 & 0.46 & 0.39 & 0.49 & 0.41 & 0.49 & 0.57 & 0.49 \\
\hline Age & 35.8 & 11.1 & 37.1 & 13.5 & 38.9 & 10.2 & 37.9 & 12.1 \\
\hline Marital status - single & 0.18 & 0.38 & 0.19 & 0.39 & 0.02 & 0.15 & 0.29 & 0.45 \\
\hline Marital status - married & 0.68 & 0.46 & 0.64 & 0.48 & 0.91 & 0.28 & 0.61 & 0.48 \\
\hline Head & 0.43 & 0.49 & 0.44 & 0.49 & 0.49 & 0.50 & 0.49 & 0.49 \\
\hline Spouse of head & 0.34 & 0.47 & 0.31 & 0.46 & 0.51 & 0.50 & 0.21 & 0.4 \\
\hline Son/daughter of head & 0.16 & 0.36 & 0.17 & 0.37 & 0 & & 0.57 & 0.42 \\
\hline Years of education & 8.07 & 3.14 & 8.17 & 3.29 & 9.28 & 3.65 & 10.77 & 3.91 \\
\hline \multicolumn{9}{|l|}{ Employment status: } \\
\hline Jefes main activity & 0.72 & 0.45 & & & & & & \\
\hline $\begin{array}{l}\text { Doing counterpart work (min } 20 \\
\text { hrs) if Jefes is main activity }\end{array}$ & 0.83 & 0.37 & & & & & & \\
\hline Jefes secondary activity & 0.28 & 0.44 & & & & & & \\
\hline $\begin{array}{l}\text { Doing counterpart work ( } \min 20 \\
\text { hrs) if Jefes is secondary activity }\end{array}$ & 0.16 & 0.36 & & & & & & \\
\hline $\begin{array}{l}\text { Doing counterpart work (min } 20 \\
\text { hrs) }\end{array}$ & 0.64 & 0.47 & & & & & & \\
\hline Employed & 0.84 & 0.36 & 0.31 & 0.46 & 0.52 & 0.50 & 0.17 & 0.38 \\
\hline Unemployed & 0.06 & 0.24 & 0.36 & 0.48 & 0.14 & 0.34 & 0.83 & 0.38 \\
\hline Inactive & 0.10 & 0.29 & 0.33 & 0.47 & 0.35 & 0.48 & - & - \\
\hline Total hours worked & 19.8 & 14.2 & 11.6 & 21.5 & & & 32.5 & 23.7 \\
\hline Total hours worked $=0$ & 0.14 & 0.34 & 0.65 & 0.47 & & & 0.19 & 0.39 \\
\hline \multicolumn{9}{|l|}{ Household characteristics: } \\
\hline H'hold size & 5.42 & 2.42 & 4.89 & 2.4 & 4.83 & 1.83 & 4.23 & 2.05 \\
\hline No. children $<18$ & 2.67 & 1.87 & 2.08 & 1.8 & 2.33 & 1.51 & 1.34 & 1.55 \\
\hline Total h'hold income & 420.9 & 302.1 & 350.2 & 323.8 & 647.3 & 917.3 & 985.6 & 1139.8 \\
\hline H'hold p.c. income & 84.1 & 59.2 & 77.4 & 71.87 & 150.1 & 226.8 & 271.8 & 378.8 \\
\hline H'hold total income net of Jefes & 246 & 292.6 & & & & & & \\
\hline H'hold p.c. income net of Jefes & 46.8 & 56.1 & & & & & & \\
\hline$\frac{\text { Jefes participation }}{\text { Eligibility criteria Jefes: }}$ & 1 & & 0 & & 0.12 & 0.32 & 0.07 & 0.26 \\
\hline $\begin{array}{l}\text { H'hold with children of head }<18 \\
\text { or handicapped member }\end{array}$ & 0.80 & 0.39 & 0.66 & 0.47 & 1 & & 0.53 & 0.49 \\
\hline $\begin{array}{l}\text { H'hold with any children }<18 \text { or } \\
\text { handicapped member }\end{array}$ & 0.95 & 0.22 & 0.84 & 0.36 & 1 & & 0.62 & 0.48 \\
\hline Individual is formal worker & 0.02 & 0.14 & 0.02 & 0.16 & 0 & & & \\
\hline $\begin{array}{l}\text { H'hold has at least one formal } \\
\text { worker }\end{array}$ & 0.15 & 0.35 & 0.19 & 0.39 & 0.28 & 0.44 & 0.53 & 0.49 \\
\hline $\begin{array}{l}\text { Eligible individual (2) any } \\
\text { children, individual not formal } \\
\text { worker) }\end{array}$ & 0.93 & 0.25 & 0.82 & 0.38 & 0.80 & 0.40 & 0.41 & 0.49 \\
\hline $\begin{array}{l}\text { Eligible individual (1) children of } \\
\text { head, individual not formal } \\
\text { worker) }\end{array}$ & 0.69 & 0.45 & 0.54 & 0.49 & 1 & & 0.26 & 0.43 \\
\hline $\begin{array}{l}\text { Eligible h'hold (h'hold with at } \\
\text { least one eligible individual (1)) }\end{array}$ & 0.79 & 0.40 & 0.64 & 0.47 & 1 & & 0.45 & 0.49 \\
\hline No. observations in the sample & 3,092 & & 1,713 & & 13,934 & & 31,374 & \\
\hline
\end{tabular}


Table 3: Descriptive statistics, cross section for October 2001

\begin{tabular}{|c|c|c|c|c|c|c|c|c|}
\hline & \multicolumn{2}{|c|}{$\begin{array}{c}\text { Jefes } \\
\text { participants }\end{array}$} & \multicolumn{2}{|c|}{$\begin{array}{c}\text { Jefes } \\
\text { applicants }\end{array}$} & \multicolumn{2}{|c|}{$\begin{array}{c}\text { Eligible } \\
\text { heads or spouses }\end{array}$} & \multicolumn{2}{|c|}{$\begin{array}{l}\text { Active adults } \\
\quad(18-65)\end{array}$} \\
\hline & Mean & st.dev. & Mean & st.dev. & Mean & st.dev. & Mean & st.dev. \\
\hline \multicolumn{9}{|l|}{ Individual demographics: } \\
\hline Male & 0.29 & 0.45 & 0.46 & 0.5 & 0.39 & 0.49 & 0.59 & 0.49 \\
\hline Age & 35.79 & 11.17 & 37.3 & 13.36 & 39.64 & 10.19 & 38.83 & 12.15 \\
\hline Marital status - single & 0.2 & 0.4 & 0.24 & 0.43 & 0.02 & 0.15 & 0.28 & 0.45 \\
\hline Marital status - married & 0.69 & 0.46 & 0.63 & 0.48 & 0.91 & 0.28 & 0.62 & 0.48 \\
\hline Head & 0.37 & 0.48 & 0.44 & 0.5 & 0.47 & 0.50 & 0.51 & 0.50 \\
\hline Spouse of head & 0.39 & 0.49 & 0.3 & 0.46 & 0.53 & 0.50 & 0.20 & 0.40 \\
\hline Son/daughter of head & 0.19 & 0.39 & 0.19 & 0.39 & 0.00 & 0.00 & 0.24 & 0.43 \\
\hline Years of education & 8.24 & 3.2 & 7.94 & 3.34 & 9.05 & 3.72 & 10.59 & 3.94 \\
\hline \multicolumn{9}{|l|}{ Employment status: } \\
\hline Employed & 0.43 & 0.5 & 0.44 & 0.5 & 0.46 & 0.50 & 0.83 & 0.37 \\
\hline Unemployed & 0.19 & 0.39 & 0.19 & 0.39 & 0.14 & 0.34 & 0.17 & 0.37 \\
\hline Inactive & 0.38 & 0.48 & 0.36 & 0.48 & 0.41 & 0.49 & 0 & \\
\hline Total hours worked & 13.9 & 21.5 & 14.6 & 22.7 & 18.7 & 26.2 & 34.31 & 24.3 \\
\hline Hours worked $=0$ & 0.58 & 0.49 & 0.57 & 0.49 & 0.55 & 0.47 & 0.19 & 0.39 \\
\hline \multicolumn{9}{|l|}{ employment status ${ }^{*}$ gender: } \\
\hline male*employed & $\underline{0.66}$ & 0.48 & 0.56 & 0.5 & & & & \\
\hline male*unemployed & 0.26 & 0.44 & 0.28 & 0.45 & & & & \\
\hline male*inactive & $\underline{0.08}$ & 0.08 & 0.15 & 0.08 & & & & \\
\hline female*employed & 0.36 & 0.48 & 0.33 & 0.36 & & & & \\
\hline female*unemployed & 0.16 & 0.32 & 0.11 & 0.32 & & & & \\
\hline female*inactive & $\underline{0.48}$ & 0.5 & 0.55 & 0.5 & & & & \\
\hline \multicolumn{9}{|l|}{ Household characteristics: } \\
\hline HH size & 5.58 & 2.51 & 5.12 & 2.61 & 4.96 & 1.88 & 4.35 & 2.12 \\
\hline Nominal h'hold income & 426.4 & 366.7 & 427.2 & 369.1 & 692.8 & 998.3 & 980.2 & 1130.2 \\
\hline Nominal h'hold income per capita & 84.5 & 81.3 & 98.4 & 95 & 156.5 & 237.9 & 279.9 & 363.2 \\
\hline \multicolumn{9}{|l|}{ Eligibility criteria Jefes: } \\
\hline $\begin{array}{l}\text { H'hold with children of head }<18 \text { or } \\
\text { handicapped member } \\
\text { H'hold with any children }<18 \text { or }\end{array}$ & 0.80 & 0.40 & 0.67 & 0.46 & 1 & & 0.53 & 0.49 \\
\hline $\begin{array}{l}\text { H'hold with any children }<18 \text { or } \\
\text { handicapped member }\end{array}$ & 0.94 & 0.22 & 0.79 & 0.40 & & & 0.61 & 0.48 \\
\hline Individual is formal worker & 0.03 & 0.18 & 0.06 & 0.23 & 0 & & 0.39 & 0.48 \\
\hline $\begin{array}{l}\text { H'hold with at least one formal } \\
\text { worker }\end{array}$ & 0.19 & 0.40 & 0.25 & 0.43 & 0.29 & 0.46 & 0.56 & 0.49 \\
\hline $\begin{array}{l}\text { Eligible individual (children of } \\
\text { head, individual not formal worker) }\end{array}$ & 0.67 & 0.47 & 0.52 & 0.50 & 1 & & 0.26 & 0.43 \\
\hline $\begin{array}{l}\text { Eligible household (h'hold with at } \\
\text { least one eligible individual) }\end{array}$ & 0.78 & 0.41 & 0.65 & 0.47 & 1 & & 0.44 & 0.49 \\
\hline No. observations & 1222 & & 679 & & 5,273 & & 11,401 & \\
\hline
\end{tabular}


Table 4: Distribution of shocks: actual and simulated changes in real household income between Oct 2001 and Oct 2002

\begin{tabular}{|c|c|c|c|c|c|c|}
\hline & $\begin{array}{l}\text { Applicants } \\
\text { actual } \\
\text { Percentiles }\end{array}$ & $\begin{array}{l}\text { Jefes actual } \\
\text { Percentiles }\end{array}$ & $\begin{array}{c}\text { Jefes } \\
\text { (assuming zero } \\
\text { foregone } \\
\text { income) } \\
\text { Percentiles }\end{array}$ & $\begin{array}{c}\text { Jefes } \\
\text { (assuming 1/3 } \\
\text { foregone } \\
\text { income) } \\
\text { Percentiles }\end{array}$ & $\begin{array}{c}\text { Jefes } \\
\text { (assuming } 1 / 2 \\
\text { foregone } \\
\text { income) } \\
\text { Percentiles }\end{array}$ & $\begin{array}{c}\text { Jefes (with } \\
\text { estimated } \\
\text { foregone } \\
\text { income) } \\
\text { Percentiles }\end{array}$ \\
\hline \multicolumn{7}{|c|}{ Household income } \\
\hline $1 \%$ & -2187.9 & -1688.5 & -1838.5 & -1788.5 & -1763.5 & -1759.8 \\
\hline $5 \%$ & -994.0 & -1004.6 & -1154.6 & -1104.6 & -1079.6 & -1127.9 \\
\hline $10 \%$ & -730.9 & -647.7 & -797.7 & -747.7 & -722.7 & -756.7 \\
\hline $25 \%$ & -410.3 & -306.7 & -456.7 & -406.7 & -381.7 & -398.2 \\
\hline Median & -168.2 & -68.2 & -218.2 & -168.2 & -143.2 & -172.1 \\
\hline $75 \%$ & 0.0 & 103.0 & -47.0 & 3.0 & 28.0 & 22.1 \\
\hline $90 \%$ & 123.3 & 252.7 & 102.7 & 152.7 & 177.7 & 169.7 \\
\hline $95 \%$ & 280.0 & 364.5 & 214.5 & 264.5 & 289.5 & 272.8 \\
\hline $99 \%$ & 500.0 & 685.7 & 535.7 & 585.7 & 610.7 & 564.1 \\
\hline Mean & -258.9 & -151.7 & -301.7 & -251.7 & -226.7 & -242.1 \\
\hline Std. Dev. & 450.6 & 434.1 & 434.1 & 434.1 & 434.1 & 437.5 \\
\hline \multicolumn{7}{|c|}{ Individual income } \\
\hline $1 \%$ & -775.2 & -825.8 & -975.8 & -925.8 & -900.8 & -1032.2 \\
\hline $5 \%$ & -446.1 & -337.9 & -487.9 & -437.9 & -412.9 & -469.8 \\
\hline $10 \%$ & -318.2 & -198.5 & -348.5 & -298.5 & -273.5 & -318.0 \\
\hline $25 \%$ & -139.4 & -59.1 & -209.1 & -159.1 & -134.1 & -144.8 \\
\hline Median & 0.0 & 140.0 & -10.0 & 40.0 & 65.0 & 45.8 \\
\hline $75 \%$ & 0.0 & 150.0 & 0.0 & 50.0 & 75.0 & 77.4 \\
\hline $90 \%$ & 88.5 & 150.0 & 0.0 & 50.0 & 75.0 & 90.1 \\
\hline $95 \%$ & 150.0 & 190.0 & 40.0 & 90.0 & 115.0 & 109.4 \\
\hline $99 \%$ & 293.0 & 300.0 & 150.0 & 200.0 & 225.0 & 181.8 \\
\hline Mean & -77.3 & 28.8 & -121.2 & -71.2 & -46.2 & -61.2 \\
\hline Std. Dev. & 213.3 & 214.6 & 214.6 & 214.6 & 214.6 & 226.3 \\
\hline
\end{tabular}

Note: the estimated foregone income is based on the SD estimates on individual income in October 2002. 
Table 5: Initial location of participants and applicants in the national distribution of income (Oct 2001), panel sample

\begin{tabular}{ccccc}
\hline & \multicolumn{2}{c}{$\begin{array}{c}\text { Jefes participants } \\
(\%)\end{array}$} & \multicolumn{2}{c}{$\begin{array}{c}\text { Jefes applicants } \\
(\%)\end{array}$} \\
\hline $\begin{array}{c}\text { Deciles of 2001 } \\
\text { h'hold income } \\
\text { per capita }\end{array}$ & Households & individuals & Households & Individuals \\
\hline 1 & 18.47 & 15.94 & 14.79 & \\
2 & 32.99 & 25.75 & 27.80 & 20.95 \\
3 & 21.25 & 14.39 & 23.76 & 14.90 \\
4 & 10.56 & 16.57 & 9.98 & 17.26 \\
5 & 7.99 & 10.28 & 7.14 & 9.41 \\
6 & 4.07 & 7.87 & 6.12 & 6.85 \\
7 & 3.44 & 4.99 & 7.38 & 7.07 \\
8 & 0.17 & 3.14 & 1.97 & 5.30 \\
9 & 0.59 & 0.29 & 0.83 & 2.59 \\
10 & 0.46 & 0.78 & 0.22 & 0.37 \\
\hline
\end{tabular}

Table 6: Initial location of eligible active adults in the national distribution of income (Oct 2001), panel sample

\begin{tabular}{cccc}
\hline $\begin{array}{c}\text { Deciles of 2001 } \\
\text { h'hold income } \\
\text { per capita }\end{array}$ & $\begin{array}{c}\text { Eligible } \\
\text { Households } \\
(\%)\end{array}$ & $\begin{array}{c}\text { Individuals } \\
(\%)\end{array}$ & $\begin{array}{c}\text { Theoretical } \\
\text { eligibility } \\
(\%)\end{array}$ \\
\hline 1 & 12.3 & 14.2 & 30.7 \\
2 & 14.6 & 16.2 & 26.9 \\
3 & 10.3 & 10.9 & 7.8 \\
4 & 12.7 & 12.7 & 11.8 \\
5 & 12.1 & 11.8 & 8.5 \\
6 & 11.1 & 10.1 & 4.7 \\
7 & 8.2 & 7.3 & 4.1 \\
8 & 8.1 & 7.4 & 3.7 \\
9 & 6.3 & 5.5 & 1.7 \\
10 & 4.4 & 4.1 & 0.1 \\
\hline
\end{tabular}

Note: "Theoretical eligibility" is defined as a household with dependents (of the head), for which the head is unemployed and the Jefes participant is the head. 
Table 7: Location of Jefes participants in the cross-sectional distribution of income

\begin{tabular}{|c|c|c|c|c|c|c|}
\hline \multicolumn{7}{|c|}{ Assuming zero foregone income } \\
\hline \multirow{2}{*}{$\begin{array}{l}\text { Deciles of h'hold } \\
\text { income per capita (net } \\
\text { of the transfer) }\end{array}$} & \multicolumn{2}{|c|}{$\begin{array}{c}\text { Trabajar participants } 1997 \\
(\%)\end{array}$} & \multicolumn{2}{|c|}{$\begin{array}{c}\text { Jefes participants } 2002 \\
(\%)\end{array}$} & \multicolumn{2}{|c|}{$\begin{array}{l}\text { Eligible } \\
(\%)\end{array}$} \\
\hline & households & individuals & households & individuals & households & individuals \\
\hline 1 & 58.2 & 60.1 & 28.9 & 29.0 & 13.5 & 14.4 \\
\hline 2 & 17.5 & 18.5 & 23.2 & 23.5 & 11.3 & 13.6 \\
\hline 3 & 9.9 & 9.5 & 18.6 & 18.6 & 12.2 & 13.7 \\
\hline 4 & 6.8 & 5.8 & 12.9 & 13.1 & 12.6 & 12.7 \\
\hline 5 & 2.2 & 1.9 & 8.9 & 8.5 & 11.7 & 10.8 \\
\hline 6 & 2.5 & 1.6 & 5.1 & 4.9 & 11.0 & 10.2 \\
\hline 7 & 1.7 & 1.6 & 1.5 & 1.6 & 8.9 & 8.2 \\
\hline 8 & 0.6 & 0.5 & 0.6 & 0.5 & 7.2 & 6.5 \\
\hline 9 & 0.4 & 0.3 & 0.3 & 0.3 & 6.8 & 5.9 \\
\hline \multirow[t]{2}{*}{10} & 0.2 & 0.1 & 0.1 & 0.1 & 4.9 & 4.2 \\
\hline & & the estimate & foregone inc & & & \\
\hline \multirow{2}{*}{$\begin{array}{l}\text { Deciles of h'hold } \\
\text { income per capita } \\
\text { (net of the net gains) }\end{array}$} & Trabajar pai & $\begin{array}{l}\text { icipants } 1997 \\
\text { o) }\end{array}$ & \multicolumn{2}{|c|}{$\begin{array}{c}\text { Jefes participants } 2002 \\
(\%)\end{array}$} & & \\
\hline & ind & iduals & households & individuals & & \\
\hline 1 & & 8.1 & 3.6 & 19.5 & & \\
\hline 2 & & 7.7 & 41.0 & 27.4 & & \\
\hline 3 & & 3.5 & 27.7 & 20.2 & & \\
\hline 4 & & 7.3 & 13.9 & 15.2 & & \\
\hline 5 & & .7 & 8.7 & 9.1 & & \\
\hline \multirow[t]{2}{*}{6} & & .7 & & & & \\
\hline & (deci & es 6-10) & 3.3 & 5.2 & & \\
\hline 7 & & & 1.3 & 2.3 & & \\
\hline 8 & & & 0.4 & 0.9 & & \\
\hline 9 & & & 0.1 & 0.2 & & \\
\hline 10 & & & 0.1 & 0.1 & & \\
\hline
\end{tabular}

Data sources: Trabajar: Encuesta de Desarrollo Social 1997 (zero foregone income from

Table 2, net gains estimates from Table 5 ("non parametric method") in Jalan and Ravallion (2003);

Jefes: own calculations from EPH October 2002. 
Table 8: Probits for calibrating the propensity scores: Jefes participants vs. applicants

\begin{tabular}{|c|c|c|c|c|c|}
\hline \multicolumn{4}{|c|}{$\begin{array}{l}\text { Cross-section } \\
\text { Oct } 2002\end{array}$} & \multicolumn{2}{|c|}{$\begin{array}{c}\text { Panel } \\
\text { Oct 2001-Oct } 2002\end{array}$} \\
\hline & Coeff. & t-stat & & Coeff. & t-stat \\
\hline age $18-24$ & 0.002 & 0.02 & age $18-24$ & 0.068 & 0.53 \\
\hline age $25-29$ & 0.191 & 2.25 & age $25-29$ & 0.329 & 2.62 \\
\hline age $30-39$ & 0.159 & 2.12 & age $30-39$ & 0.094 & 0.85 \\
\hline age $40-49$ & 0.334 & 4.71 & age $40-49$ & 0.275 & 2.52 \\
\hline Male & -0.371 & -6.89 & Male & -0.544 & -5.55 \\
\hline Head & 0.012 & 0.17 & Head & -0.022 & -0.19 \\
\hline Spouse of head & -0.317 & -3.8 & Spouse of head & -0.323 & -2.45 \\
\hline Single & -0.003 & -0.04 & single & -0.041 & -0.32 \\
\hline Married & 0.144 & 1.89 & married & 0.249 & 1.94 \\
\hline Incomplete primary & -0.045 & -0.51 & incomplete primary & 0.003 & 0.02 \\
\hline Complete primary & 0.013 & 0.16 & complete primary & -0.092 & -0.67 \\
\hline Incomplete secondary & 0.021 & 0.27 & incomplete secondary & -0.089 & -0.66 \\
\hline Complete secondary & 0.002 & 0.02 & complete secondary & 0.041 & 0.28 \\
\hline House - villa & 0.130 & 1.21 & house - villa & -0.089 & -0.51 \\
\hline House - departam. & -0.109 & -1.6 & house - apartment & -0.028 & -0.24 \\
\hline 1 room house & -0.196 & -2.07 & no. rooms & -0.023 & -0.82 \\
\hline 2 rooms & -0.072 & -0.86 & Bathroom & 0.022 & 0.2 \\
\hline 3 rooms & -0.130 & -1.62 & rent house & -0.222 & -1.8 \\
\hline 4 rooms & -0.117 & -1.39 & free renters & -0.404 & -3.05 \\
\hline Bathroom & -0.034 & -0.33 & walls -mamposteria & 0.002 & 0.02 \\
\hline Renting house & -0.094 & -1.34 & share members 0-5 & 1.408 & 3.27 \\
\hline Free renter & -0.117 & -1.63 & share members 6-17 & 1.421 & 3.6 \\
\hline Walls -mamposteria & -0.011 & -0.15 & share members $18-64$ & 0.468 & 1.29 \\
\hline Water - cloaca & 0.082 & 0.89 & household size & 0.010 & 0.64 \\
\hline Water - pozo & 0.151 & 1.55 & unemployed & 0.103 & 0.9 \\
\hline Water - camara & 0.073 & 0.78 & inactive & -0.115 & -1.05 \\
\hline Share members $0-5$ & 1.224 & 4.91 & public employee & 0.533 & 2.49 \\
\hline share members 6-17 & 0.956 & 4.25 & teacher & 0.333 & 1.25 \\
\hline share members 18-64 & 0.185 & 0.92 & social service & 0.251 & 1.18 \\
\hline Household size & 0.006 & 0.59 & manufacturing & 0.087 & 0.53 \\
\hline Region Noroeste & -0.373 & -4 & construction worker & 0.218 & 1.49 \\
\hline Region Nordeste & -0.173 & -1.79 & domestic worker & -0.145 & -1.1 \\
\hline Region Cuyo & -0.654 & -6.19 & region Noroeste & -0.344 & -2.4 \\
\hline Region Pampeana & -0.027 & -0.3 & region Nordeste & -0.185 & -1.24 \\
\hline Region Patagonica & -0.094 & -0.88 & region Cuyo & -0.615 & -3.76 \\
\hline & & & region Pampeana & 0.134 & 0.91 \\
\hline & & & region Patagonica & -0.212 & -1.18 \\
\hline No. Obs. & 4803 & & No. obs. & 1899 & \\
\hline no.treated off support & 6 & & no.treated off support & 28 & \\
\hline Pseudo R2 & 0.060 & & pseudo R2 & 0.0817 & \\
\hline
\end{tabular}

Note: dependent variable $=1$ if individual participated in Jefes in October 2002 and 0 otherwise. 
Table 9: Average impact on incomes and employment

\begin{tabular}{lcccccc}
\hline & $\begin{array}{c}\text { Household } \\
\text { income }\end{array}$ & $\begin{array}{c}\text { Individual } \\
\text { income }\end{array}$ & $\begin{array}{c}\text { Individual } \\
\text { employed }\end{array}$ & $\begin{array}{c}\text { Individual } \\
\text { unemployed }\end{array}$ & $\begin{array}{c}\text { Individual } \\
\text { inactive }\end{array}$ & $\begin{array}{c}\text { Total } \\
\text { hours } \\
\text { worked }\end{array}$ \\
\hline $\begin{array}{l}\text { Cross section (October 2002) } \\
E\left(Y_{1} \mid D=1\right)\end{array}$ & 438.3 & 172.9 & 0.86 & 0.04 & 0.10 & 20.6 \\
$E\left(Y_{1} \mid D=0\right)$ & 357.1 & 83.7 & 0.37 & 0.30 & 0.33 & 11.4 \\
Matched single difference & & & & & & \\
$S D=E\left(Y_{1} \mid D=1\right)-E\left(Y_{1} \mid D=0\right)$ & 81.19 & 89.2 & 0.49 & -0.26 & -0.23 & 9.2 \\
& $(16.0)$ & $(5.27)$ & $(0.02)$ & $(0.02)$ & $(0.02)$ & $(0.8)$ \\
$95 \%$ confidence interval & {$[63.8,127.6]$} & {$[81.2,101.9]$} & {$[0.45,0.52]$} & {$[-0.29,-0.22]$} & {$[-0.27,-0.18]$} & {$[8.0,11.4]$}
\end{tabular}

\section{Panel (October 2001-October 2002)}

\begin{tabular}{|c|c|c|c|c|c|c|}
\hline$E\left(Y_{1}-Y_{0} \mid D=1\right)$ & -147.2 & 30.2 & 0.42 & -0.15 & -0.27 & 6.4 \\
\hline$E\left(Y_{1}-Y_{0} \mid D=0\right)$ & -250.6 & -83.6 & -0.03 & 0.08 & -0.04 & -234 \\
\hline \multicolumn{7}{|l|}{ Matched double-difference: } \\
\hline \multirow[t]{2}{*}{$D D=E\left(Y_{1}-Y_{0} \mid D=1\right)-E\left(Y_{1}-Y_{0} \mid D=0\right)$} & 103.41 & 113.55 & 0.46 & -0.23 & -0.23 & 8.9 \\
\hline & $(32.27)$ & $(15.08)$ & $(0.04)$ & $(0.04)$ & $(0.04)$ & $(1.5)$ \\
\hline $95 \%$ confidence interval & {$[67.8,195.9]$} & {$[78.5,138.4]$} & {$[0.32,0.49]$} & {$[-0.27,-0.09]$} & {$[-0.30,-0.15]$} & {$[5.8,12.1]$} \\
\hline
\end{tabular}

Note: Standard errors in parentheses. All standard errors are bootstrapped with 100 repetitions. In the panel sample, real income figures are base 2002 (annual inflation rate of $39.4 \%)$. 
Table 10: Impact of the Jefes program on the aggregate unemployment rate

\begin{tabular}{lccccc}
\hline$\%$ & $\begin{array}{c}\text { Octual } \\
2001\end{array}$ & $\begin{array}{c}\text { May } \\
\text { October }\end{array}$ & $\begin{array}{c}\text { October } \\
2002\end{array}$ & $\begin{array}{c}\text { ONDEC calculations } \\
\text { assuming that Jefes } \\
\text { articipants would be } \\
\text { otherwise } \\
\text { unemployed* }\end{array}$ & $\begin{array}{c}\text { Our calculation } \\
\text { based on } \\
\text { estimated net } \\
\text { gains }\end{array}$ \\
\hline $\begin{array}{l}\text { Activity rate } \\
\text { (actives/total) }\end{array}$ & 42.2 & 41.8 & 42.8 & 42.9 & 42.0 \\
$\begin{array}{l}\text { Employment rate } \\
\text { (employed/total) }\end{array}$ & 34.5 & 32.8 & 35.2 & 32.7 & 33.5 \\
$\begin{array}{l}\text { Unemployment rate } \\
\text { (unemployed/actives) }\end{array}$ & 18.3 & 21.5 & 17.8 & 23.6 & 20.3 \\
\hline
\end{tabular}

Note: For comparability with previous EPH surveys, these calculations apply to 28 urban conglomerates (excluding Viedma, Rawson, San-Nicolas which were added in October 2002, as well as new areas added in the GBA). We follow INDEC in the definition of the activity/employment/unemployment rates.

* Source: INDEC (2002a).

$\dagger$ Estimated net gains on employment, unemployment and inactivity from Table 9, single difference estimates. Let actual number of employed individuals be $E_{t}$, and the number of unemployed be $U_{t}$ and $J$ be the total number of Jefes participants in October 2002. Then the actual unemployment rate is $U_{t} /\left(U_{t}+E_{t}\right)$ while the counterfactual unemployment rate is $\left(U_{t}+0.26 J\right) /\left(U_{t}+E_{t}-0.23 J\right)$. 
Table 11: Impacts on labor supply and household size

\begin{tabular}{|c|c|c|c|c|c|c|c|c|}
\hline Panel (Oct 2001-Oct 2002) & \multicolumn{3}{|c|}{ No. adult females in household: } & \multicolumn{3}{|c|}{ No. adult males in household: } & $\begin{array}{l}\text { H'hold } \\
\text { Size }\end{array}$ & $\begin{array}{c}\text { No. } \\
\text { children }\end{array}$ \\
\hline$E\left(Y_{1 t+1}-Y_{0 t} \mid D=1\right)$ & 0.39 & -0.08 & -0.27 & 0.04 & -0.04 & 0.04 & 0.05 & 0.03 \\
\hline \multicolumn{9}{|c|}{$\begin{array}{l}\text { Matched double-difference: } \\
D D_{t, t+1}=E\left(Y_{1 t+1}-Y_{0 t} \mid D=1\right)\end{array}$} \\
\hline $95 \%$ confidence interval & {$[0.17,0.39]$} & {$[-0.20,-0.03]$} & {$[-0.27,-0.06]$} & {$[-0.19,-0.02]$} & {$[-0.19,-0.02]$} & {$[-0.03,0.10]$} & {$[-0.14,0.18]$} & {$[-0.11,0.18]$} \\
\hline
\end{tabular}


Table 12: Stratification of net gains

\begin{tabular}{|c|c|c|c|c|c|}
\hline \multirow[t]{2}{*}{ Real Income impacts } & \multicolumn{3}{|c|}{ Cross section $S D$} & \multicolumn{2}{|c|}{ Panel $D D$} \\
\hline & $\begin{array}{l}\text { H'hold } \\
\text { income } \\
\text { gain }\end{array}$ & $\begin{array}{l}\text { Individual } \\
\text { income } \\
\text { gain }\end{array}$ & $\begin{array}{l}\text { Constrained } \\
\text { individual } \\
\text { income } \\
\text { gain }\end{array}$ & $\begin{array}{l}\text { H'hold } \\
\text { income } \\
\text { gain }\end{array}$ & $\begin{array}{l}\text { Individual } \\
\text { income } \\
\text { gain }\end{array}$ \\
\hline Whole sample & $\begin{array}{c}81.18 \\
(6.1)\end{array}$ & $\begin{array}{l}89.18 \\
(1.5)\end{array}$ & $\begin{array}{c}104.75 \\
(0.64)\end{array}$ & $\begin{array}{c}103.41 \\
(12.5)\end{array}$ & $\begin{array}{c}113.55 \\
(6.3)\end{array}$ \\
\hline Participant is: & & & & & \\
\hline Male & $\begin{array}{l}32.5 \\
(11.0)\end{array}$ & $\begin{array}{l}114.6 \\
(3.4)\end{array}$ & $\begin{array}{c}115.3 \\
(1.0)\end{array}$ & $\begin{array}{l}67.5 \\
(22.9)\end{array}$ & $\begin{array}{c}8.2 \\
(15.7)\end{array}$ \\
\hline Female: & $\begin{array}{l}101.9 \\
(7.3)\end{array}$ & $\begin{array}{l}78.2 \\
(1.5)\end{array}$ & $\begin{array}{l}99.4 \\
(0.8)\end{array}$ & $\begin{array}{l}119.1 \\
(14.9)\end{array}$ & $\begin{array}{l}159.7 \\
(5.5)\end{array}$ \\
\hline Head & $\begin{array}{l}-69.0 \\
(5.6)\end{array}$ & $\begin{array}{c}100.8 \\
(3.0)\end{array}$ & $\begin{array}{c}105.9 \\
(1.0)\end{array}$ & $\begin{array}{l}121.3 \\
(16.6)\end{array}$ & $\begin{array}{c}24.4 \\
(13.0)\end{array}$ \\
\hline Spouse of head & $\begin{array}{l}53.5 \\
(8.1)\end{array}$ & $\begin{array}{l}81.6 \\
(1.8)\end{array}$ & $\begin{array}{c}103.1 \\
(1.1)\end{array}$ & $\begin{array}{l}135.5 \\
(20.2)\end{array}$ & $\begin{array}{l}176.7 \\
(7.3)\end{array}$ \\
\hline $\begin{array}{l}\text { Occupation at } \\
\text { baseline: }\end{array}$ & & & & & \\
\hline Employed & & & & $\begin{array}{c}11.9 \\
(19.5)\end{array}$ & $\begin{array}{l}-1.12 \\
(11.2)\end{array}$ \\
\hline Unemployed/inactive & & & & $\begin{array}{l}175.8 \\
(15.7) \\
\end{array}$ & $\begin{array}{c}204.4 \\
(4.5) \\
\end{array}$ \\
\hline
\end{tabular}

Note: Sample standard errors are in parentheses (not bootstrapped). 
Table 13: Impact of the Jefes program on aggregate poverty rates

\begin{tabular}{lccc}
\hline $\begin{array}{l}\text { \% below the } \\
\text { poverty line }\end{array}$ & $\begin{array}{c}\text { Actual, after the } \\
\text { program }\end{array}$ & \multicolumn{2}{c}{$\begin{array}{c}\text { Counterfactual, in the absence of the } \\
\text { program }\end{array}$} \\
\cline { 3 - 4 } & & $\begin{array}{c}\text { INDEC calculations } \\
\text { (subtracting Jefes } \\
\text { income from total } \\
\text { household income) }\end{array}$ & $\begin{array}{c}\text { Our calculation } \\
\text { based on } \\
\text { estimated net } \\
\text { gains }\end{array}$ \\
\hline $\begin{array}{l}\text { Greater Buenos Aires } \\
\text { Poverty }\end{array}$ & & & \\
Individuals & 54.3 & 54.7 & 54.5 \\
Households & 42.3 & 42.6 & 42.5 \\
Indigence & & & 26.2 \\
Individuals & 24.7 & 27.0 & 18.0 \\
Households & 16.9 & & 57.9 \\
\hline $\begin{array}{l}\text { Total 31 conglomerates } \\
\text { Poverty }\end{array}$ & & & 46.1 \\
Individuals & 57.5 & 58.1 & 29.6 \\
Households & 45.7 & 46.2 & 21.1 \\
Indigence & & 30.5 & \\
Individuals & & & \\
Households & 27.5 & & \\
\hline
\end{tabular}

Note: Income per adult equivalent are constructed using the adult equivalent scales provided by INDEC. For the analysis, new areas interviewed were excluded as well as households with partial income responses.

* Source: INDEC (2002b), INDEC(2003).

$\dagger$ Estimated net gains on income from Table 8, single difference individual estimates. 
Table 14: Measures of protection/promotion for Jefes participants

Official poverty lines

Actual joint distribution

\begin{tabular}{ccc|c} 
& non-poor 2002 & poor 2002 & \\
non-poor 2001 & 0.07 & 0.20 & 0.27 \\
poor 2001 & 0.02 & 0.71 & 0.73 \\
\cline { 2 - 3 } & 0.09 & 0.91 & 1
\end{tabular}

Counterfactual joint distribution $\dagger$

$$
\begin{gathered}
\text { non-poor } 2001 \\
\text { poor } 2001
\end{gathered}
$$

\begin{tabular}{cc|c} 
non-poor 2002 & poor 2002 & \\
0.04 & 0.22 & 0.27 \\
0.01 & 0.72 & 0.73 \\
\hline 0.06 & 0.94 & 1
\end{tabular}

\section{Official indigence line (food poverty line)}

Actual joint distribution

non-poor 2001
poor 2001

\begin{tabular}{cc|c} 
non-poor 2002 & poor 2002 & \\
0.39 & 0.30 & 0.68 \\
0.08 & 0.24 & 0.32 \\
\cline { 1 - 2 } 0.47 & 0.53 & 1
\end{tabular}

Counterfactual joint distribution $\dagger$

\begin{tabular}{cc|c} 
non-poor 2002 & poor 2002 & \\
0.28 & 0.40 & 0.68 \\
0.05 & 0.27 & 0.32 \\
\cline { 1 - 2 } 0.33 & 0.67 & 1
\end{tabular}

Note: Income per adult equivalent is constructed using the adult equivalent scales. Equivalence scales, poverty and indigence lines from INDEC (2002b, 2002c, 2003). $\dagger$ Estimated net gains for 2002 from Table 8, single difference individual estimates. 
Table A1: Comparison of survey-based participation rates with the administrative data

\begin{tabular}{|c|c|c|c|c|c|c|c|c|}
\hline \multirow{3}{*}{$\frac{\text { Conglomerates }}{\text { Tucumán }}$} & \multicolumn{4}{|c|}{$\begin{array}{l}\text { Grossed-up EPH estimates of } \\
\text { number of participants }\end{array}$} & \multicolumn{4}{|c|}{ Administrative data } \\
\hline & \multirow{2}{*}{$\frac{\text { Point estimate }}{30,454}$} & \multicolumn{3}{|c|}{$\begin{array}{l}95 \% \text { confidence } \\
\text { interval }\end{array}$} & \multicolumn{2}{|l|}{$\begin{array}{c}\text { Registered in } \\
\text { municipalities } \\
\text { covered by EPH }\end{array}$} & \multicolumn{2}{|l|}{$\begin{array}{c}\text { Domiciled in } \\
\text { municipalities } \\
\text { covered by EPH }\end{array}$} \\
\hline & & {$[23,451$} & 37,457 & ] & 38,829 & $*$ & 29,387 & \\
\hline Tierra del Fuego & 2,341 & {$[1,494$} & 3,188 & ] & 2,694 & & 2,277 & \\
\hline Santiago del Estero & 11,813 & {$[8,828$} & 14,798 & ] & 23,404 & $*$ & 22,066 & $*$ \\
\hline Santa Cruz & 1,378 & {$\left[\begin{array}{ll}839 \\
8\end{array}\right.$} & 1,917 & ] & 1,584 & & 1,362 & \\
\hline San Luis & 3,701 & {$[2,496$} & 4,906 & ] & 6,607 & $*$ & 6,361 & $*$ \\
\hline San Juan & 12,053 & {$[8,988$} & 15,118 & ] & 21,131 & $*$ & 16,185 & $*$ \\
\hline Salta & 23,592 & {$[19,243$} & 27,941 & ] & 31,948 & $*$ & 28,412 & * \\
\hline Rio Negro & 3,049 & {$[\quad 2,028$} & 4,070 & ] & 2,840 & & 3,706 & \\
\hline Neuquen & 8,411 & {$[\quad 6,469$} & 10,353 & ] & 8,831 & & 8,132 & \\
\hline Misiones & 11,164 & {$[8,302$} & 14,026 & ] & 11,997 & & 10,337 & \\
\hline Mendoza & 20,001 & {$[14,460$} & 25,542 & ] & 31,686 & $*$ & 21,828 & \\
\hline La Rioja & 7,014 & {$[5,671$} & 8,357 & ] & 9,768 & $*$ & 8,751 & $*$ \\
\hline La Pampa & 2,710 & {$\left[\begin{array}{ll}1,832 \\
\end{array}\right.$} & 3,588 & ] & 2,956 & & 2,890 & \\
\hline Jujuy & 15,542 & {$[11,996$} & 19,088 & ] & 26,834 & $*$ & 25,718 & $*$ \\
\hline Formosa & 16,865 & {$[14,037$} & 19,693 & ] & 21,513 & $*$ & 20,431 & * \\
\hline Gran Parana & 6,667 & {$[4,872$} & 8,462 & ] & 8,185 & & 7,729 & \\
\hline Concordia & 5,155 & {$[3,844$} & 6,466 & ] & 7,861 & $*$ & 7,643 & * \\
\hline Corrientes & 16,325 & {$[12,840$} & 19,810 & ] & 27,111 & $*$ & 15,936 & \\
\hline Rio Cuarto & 4,455 & {$[3,093$} & 5,817 & ] & 6,503 & $*$ & 5,796 & \\
\hline Gran Cordoba & 53,380 & {$[40,058$} & 66,702 & ] & 48,067 & & 46,317 & \\
\hline C.Rivadavia & 1,851 & {$[1,049$} & 2,653 & ] & 2,988 & $*$ & 2,735 & * \\
\hline Rawson & 4,310 & {$[3,169$} & 5,451 & ] & 4,467 & & 4,018 & \\
\hline Chaco & 21,709 & {$[16,060$} & 27,358 & ] & 36,729 & $*$ & 34,082 & $*$ \\
\hline Catamarca & 10,955 & {$[9,046$} & 12,864 & ] & 14,879 & $*$ & 15,499 & * \\
\hline Gran Rosario & 56,920 & {$[43,906$} & 69,934 & ] & 79,361 & $*$ & 75,631 & * \\
\hline Gran Santa Fe & 23,628 & {$[19,255$} & 28,001 & ] & 29,513 & $*$ & 28,577 & * \\
\hline Villa Consitucion & 8,224 & {$[5,276$} & 11,172 & ] & 6,353 & & 7,124 & \\
\hline Capital Federal & 27,008 & {$[10,677$} & 43,339 & ] & 55,437 & $*$ & 49,421 & * \\
\hline Conurbano & 379,009 & {$[311,738$} & 446,280 & ] & 418,018 & & 369,349 & \\
\hline La Plata & 28,593 & [ 21,184 & 36,002 & ] & 25,960 & & 23,885 & \\
\hline Bahía Blanca & 6,375 & {$[\quad 3,502$} & 9,248 & ] & 5,244 & & 5,367 & \\
\hline Mar del Plata & 16,754 & {$[10,788$} & 22,720 & ] & 16,789 & & 15,706 & \\
\hline Total Urban Areas & 841,406 & {$[767,394$} & 915,418 & ] & $1,036,087$ & $*$ & 922,658 & $*$ \\
\hline
\end{tabular}

Note: * significantly different from that implied by the survey data. Standard errors corrected for complex survey design were provided by INDEC.

${ }^{\dagger}$ Source: Calculations (kindly provided by the Ministry of Labor) are based on overlapping the database of liquidacion de beneficiarios (MTESS) and base de personas (ANSES) 
Figure 1: Concentration curves for the Jefes and Trabajar programs

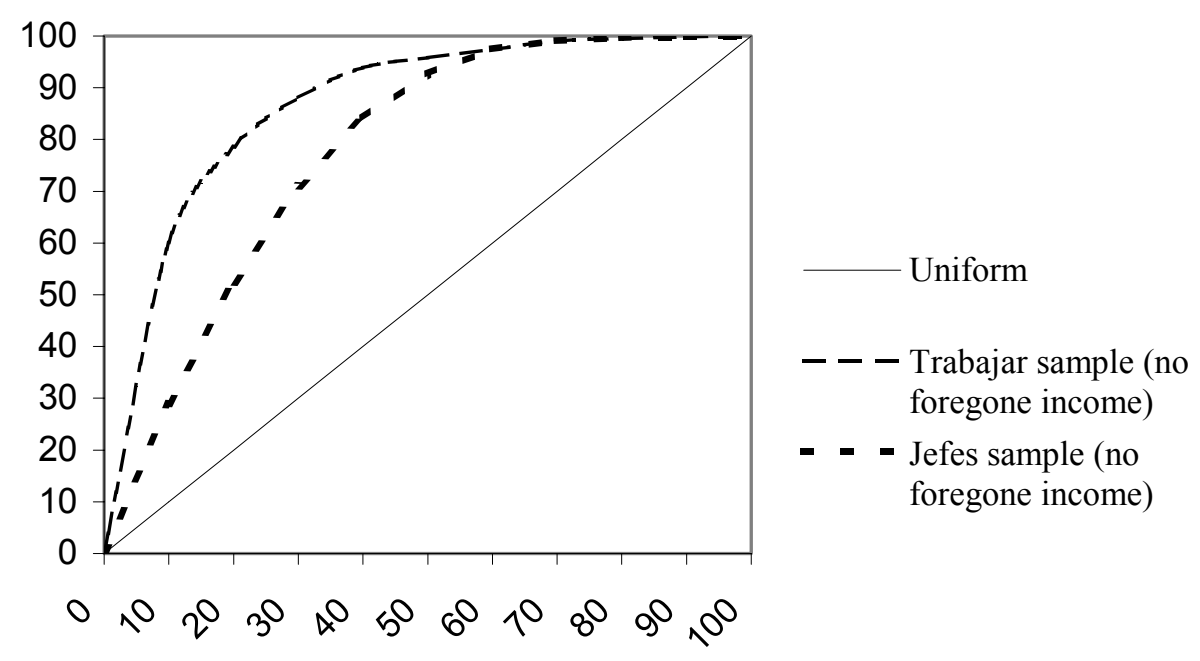

Note: Concentration curves for zero foregone income (individuals); see Table 7.

Figure 2: Eligibility of Jefes participants: cumulative distributions of income post-intervention (October 2002)

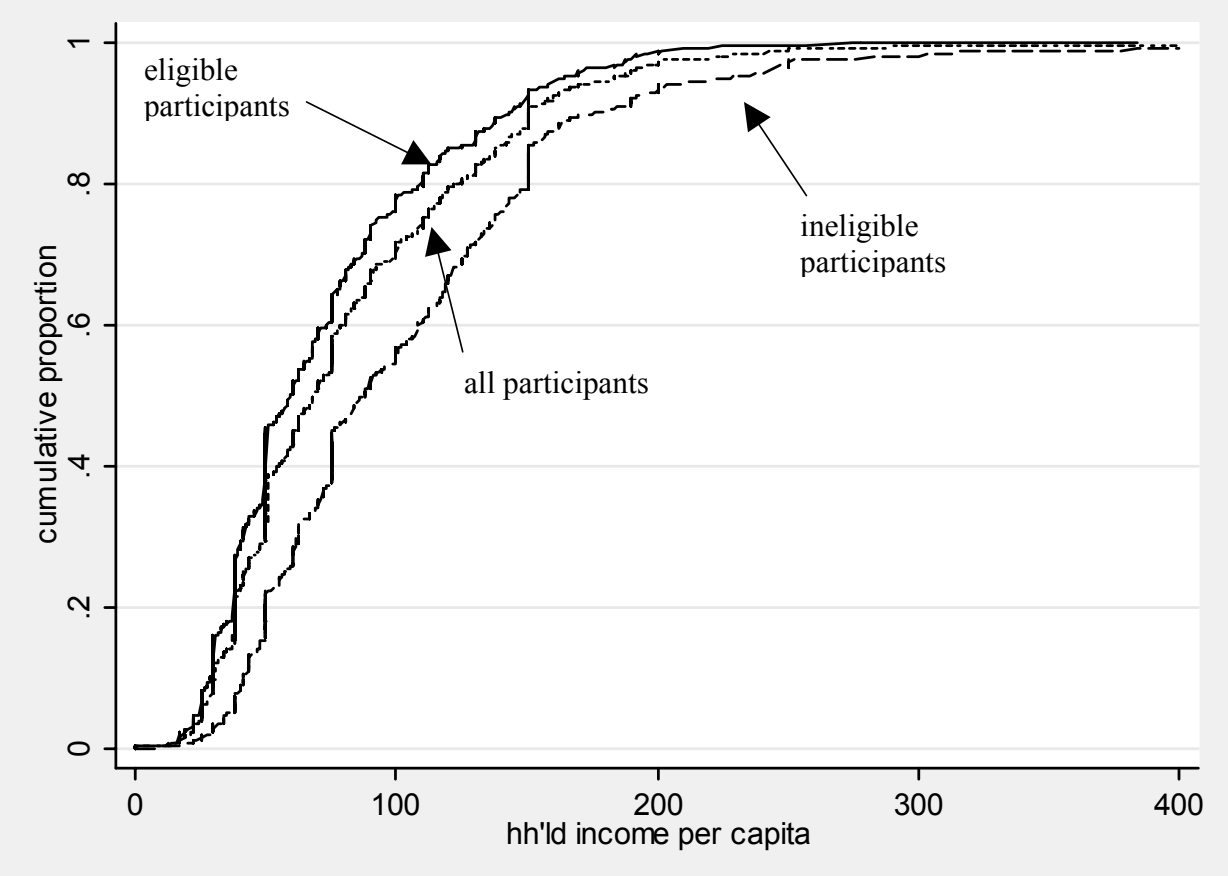


Figure 3: Overlapping support in the distribution of the propensity score

Panel sample:

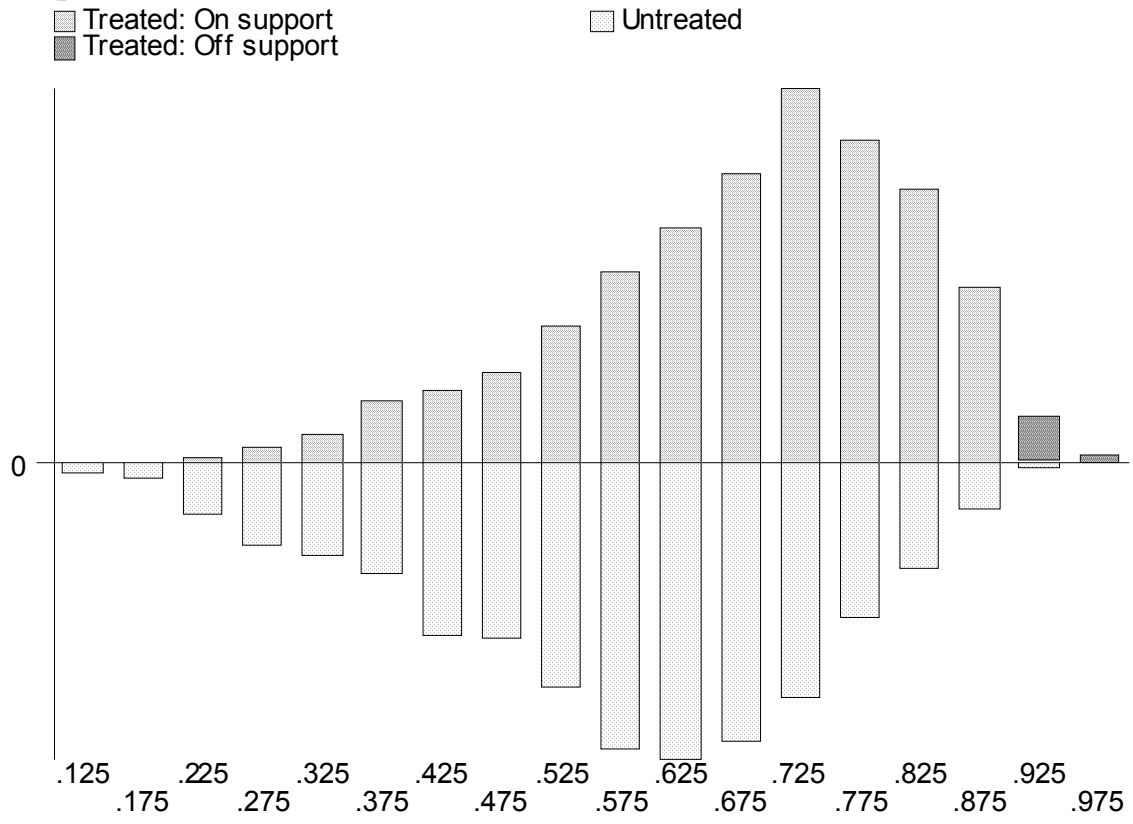

Note: histogram of propensity score distribution for Jefes participants (treated) and Jefes applicants (untreated). 28 $(2 \%)$ of the participants are off the common support.

Cross-section sample:

$\square$ Treated: On support

Treated: Off support

$\square$ Untreated

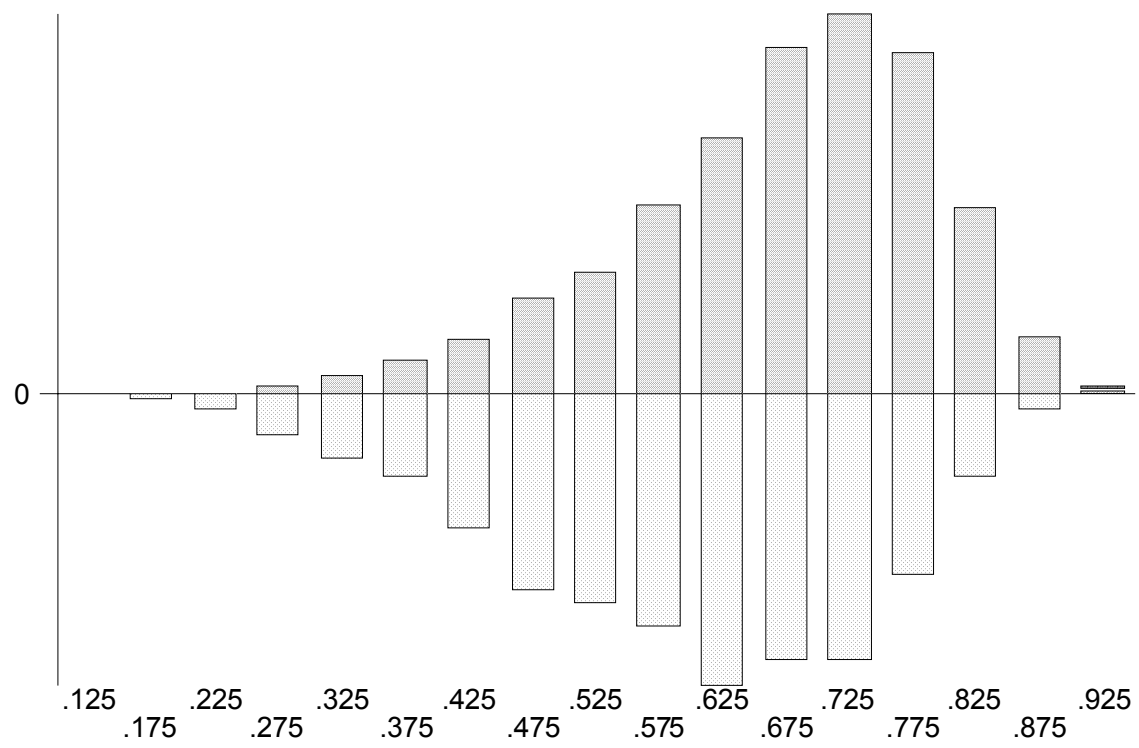

Note: histogram of propensity score distribution for Jefes participants (treated) and Jefes applicants (untreated). 6 $(0.2 \%)$ of the participants are off the common support. 
Figure 4: Impacts on poverty amongst Jefes participants: cumulative distributions of income pre- and post-intervention

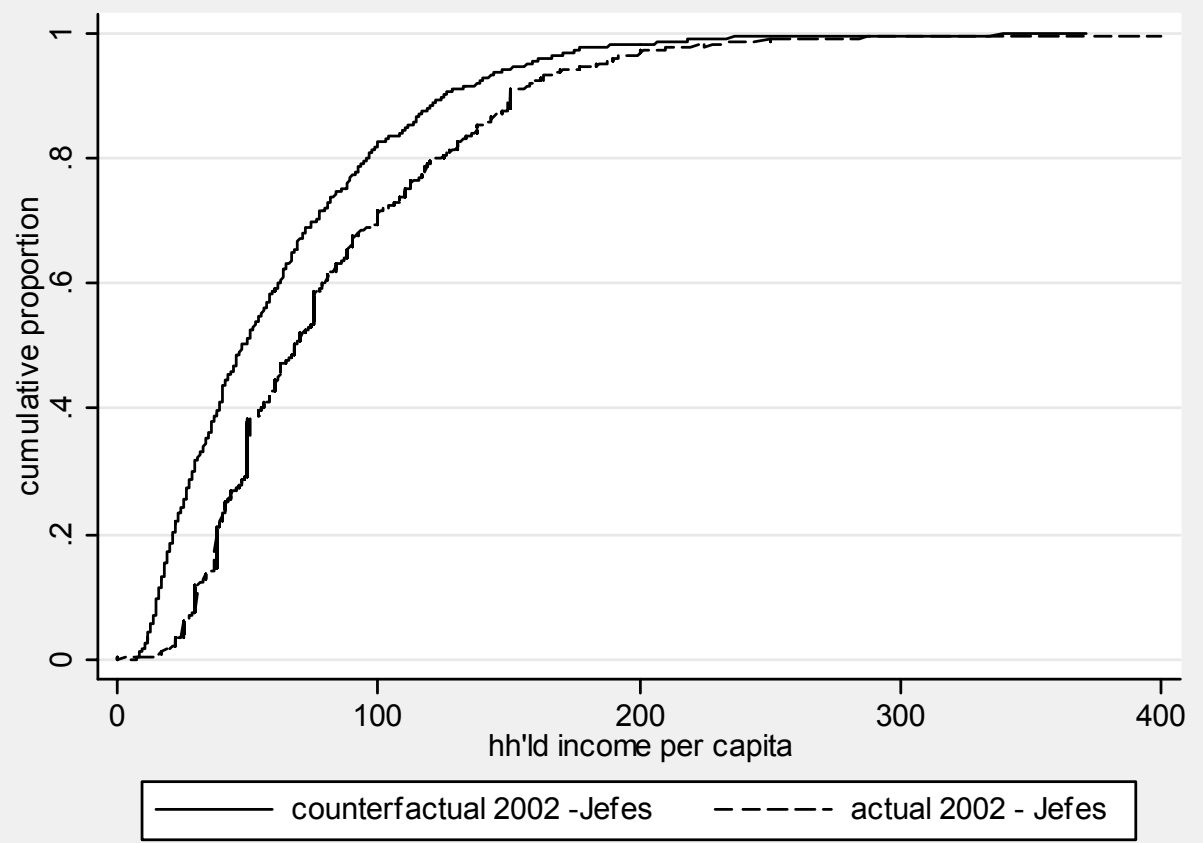

Note: the counterfactual distribution is based on the single difference individual income estimates of net gains from the program.

Figure 5: Impacts on poverty nationally: cumulative distributions of income pre- and post-intervention

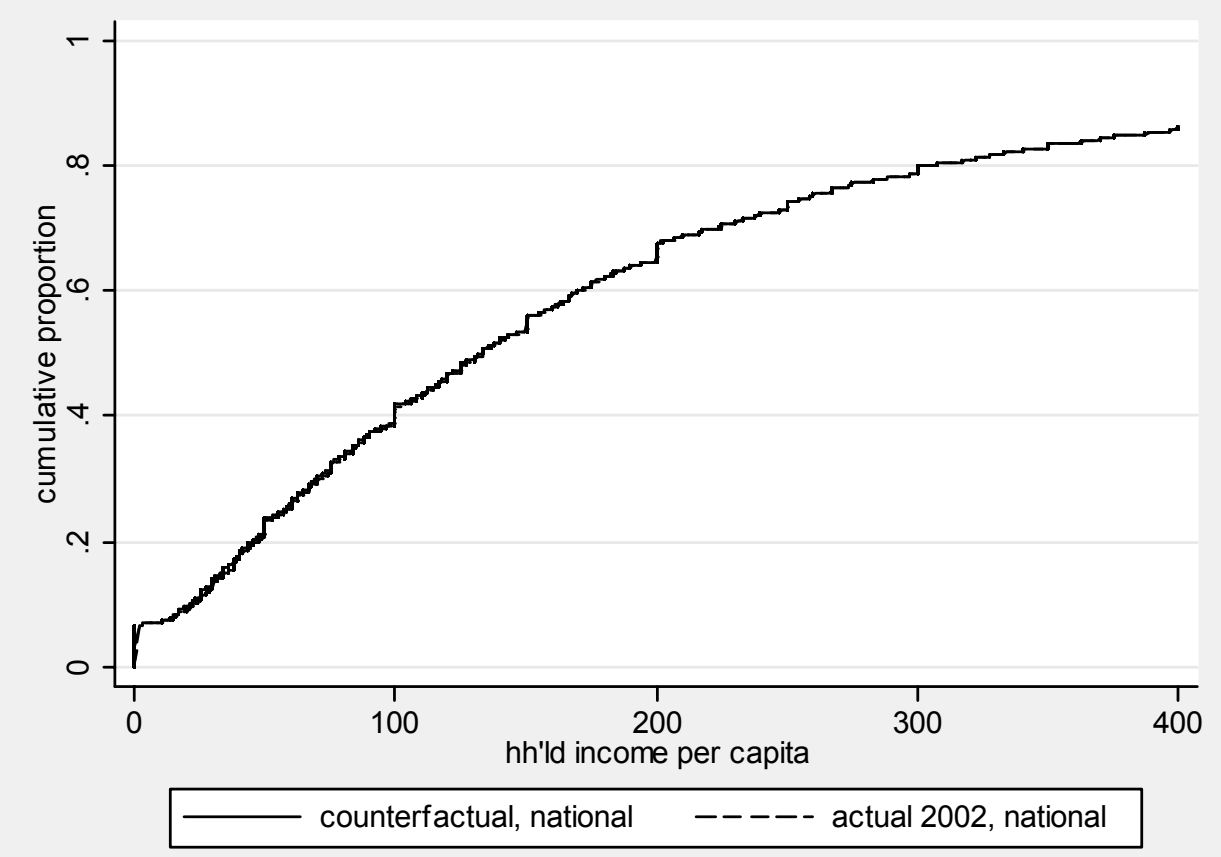

Note: the counterfactual distribution is based on the single difference individual income estimates of net gains from the program. 